\section{A dinâmica recente do transporte marítimo de cabotagem e longo curso no Brasil}

\author{
Nelson Fernandes Felipe Junior \\ Departamento de Geografia, Programa de Pós-graduação em Geografia, Centro de Educação \\ e Ciências Humanas, Universidade Federal de Sergipe, Brasil.
}

Recebido: 2 de abril de 2018. Aceptado: 13 de noviembre de 2018 .

\begin{abstract}
Resumo
O presente artigo realiza uma análise do transporte marítimo de cabotagem e longo curso no Brasil, considerando os fluxos, as modernizações, a importância da logística privada e de Estado, além de apontar algumas reestruturações do setor portuário e marítimo. $\mathrm{O}$ transporte de cabotagem e longo curso é relevante para o desenvolvimento econômico brasileiro, para o escoamento de mercadorias e imprescindível para atender às demandas corporativas e humanas. Fomenta as interações inter-regionais e do Brasil com outros países, intensifica as redes e os fluxos no espaço e realiza a articulação entre os produtores e o mercado. Há uma modernização relativa do setor portuário e marítimo brasileiro, todavia, este apresenta diversos pontos de estrangulamento que prejudicam o crescimento econômico nacional.
\end{abstract}

\section{The recent dynamics of maritime transport of cabotage and long distance in Brazil}

\begin{abstract}
This article presents an analysis of cabotage and long course shipping in Brazil, considering the flows, modernizations, the importance of private and State logistics, as well pointing some restructuring of the port and maritime sector. Cabotage and long course transport is relevant to Brazilian economic development, to the flow of goods and essential to meet corporate and human demands. Encourages interregional and Brazilian interactions with other countries, intensifies networks and flows in space and realizes the articulation between producers and the market. There is a relative modernization of the Brazilian port and maritime sector, however, it presents several bottlenecks that damaging national economic growth.
\end{abstract}

\section{Palavras-chave}

Transporte Marítimo Circulação do Capital Desenvolvimento Modernização

\section{Keywords}

Sea Transportation Circulation of Capital Development Modernization

Palabras clave

Transporte Marítimo Circulación del Capital Desarrollo Modernización 


\section{Introdução}

Muitos portos (no Brasil e no mundo) surgiram a partir de estratégias e ações do Estado na busca pela dinâmica econômica. São fatores-chave da ocupação demográfica, do fomento das atividades econômicas, possuíram - juntamente com os fortes - a função de proteção do território (relevância geopolítica), têm participação no processo de interiorização econômica, contribuíram para a consolidação política dos territórios ao longo do tempo, os portos intensificam as atividades urbanas (comércio, serviços e indústrias) e rurais (agropecuária), estimulam os fluxos migratórios, entre outros. Dessa maneira, os portos não são apenas pontos nodais para transbordo e movimentação de mercadorias, mas componentes da formação política e econômica dos diferentes países ao longo do tempo.

$\mathrm{O}$ avanço do sistema de transportes facilita a mobilidade e a acessibilidade e reduz o tempo de deslocamento no espaço. A participação do Estado é fundamental para o desenvolvimento econômico, para o fomento do transporte marítimo e para a circulação e a mobilidade geográfica do capital. Segundo Rangel (2005), a partir de políticas setoriais, fiscais, monetárias, cambiais e de estímulo ao crédito, o poder público influencia a distribuição dos fatores de produção no território, ao mesmo tempo em que se intensifica o consumo interno, as exportações, as importações e a movimentação de navios cargueiros e contêineres (fomento do transporte marítimo).

Com a reestruturação econômica e produtiva, as tecnologias ligadas à circulação, a grande capacidade dos navios cargueiros e a otimização logística, têm-se intensas repercussões na produção e no comércio. Grandes quantidades de cargas, atualmente, podem ser transportadas em menos tempo e com custos mais baixos, aparecendo sucessivamente no mercado (reabastecimento rápido do estoque), não sendo necessário, portanto, a armazenagem em larga escala na forma de capital-mercadoria latente. Com o aprimoramento da logística e a expansão do transporte marítimo, o retorno do dinheiro aplicado ocorre em períodos mais curtos, de modo que parte da mercadoria se transforma continuamente em capital-dinheiro, enquanto a outra parte circula no espaço como capital-mercadoria em condições de ser comercializada (Marx, 2005).

O transporte marítimo não representa um fim em si mesmo, ou seja, é um meio de servir a outros objetivos e outras demandas. A atividade produtiva é dependente do transporte marítimo internacional para conquistar mercados externos, ao passo que a cabotagem tem como objetivo principal subsidiar a cadeia de suprimentos interna (demandas sociais e econômicas). O sistema de transportes e, em especial, o modal marítimo é, por um lado, um reflexo da economia regional/nacional e, por outro, um fator que impulsiona o desenvolvimento econômico. Infere-se, portanto, que o transporte marítimo de cargas é subsidiário à produção e, ao mesmo tempo, importante para completar a rotatividade do capital (Marx, 2005).

A multimodalidade/intermodalidade, por sua vez, é imprescindível para o transporte hidroviário, já que o transbordo e as conexões entre os modais aquaviário e terrestres (ferrovia, rodovia e dutovia) são necessários, assim, o termo "complexo portuário" representa os sistemas técnicos existentes, a integração entre as diferentes modalidades de transporte, bem como os diversos agentes e instituições que atuam no funcionamento dos portos e terminais privados.

Diante disso, o presente artigo possui como objetivo realizar uma análise da dinâmica recente do transporte marítimo de cabotagem e, sobretudo do longo curso no Brasil, destacando a relevância da circulação para a economia nacional, algumas estratégias e ações públicas e privadas no setor, os avanços e gargalos setoriais (tangíveis e intangíveis), além de apontar propostas para fomentar o sistema portuário no Brasil. 
No que tange aos procedimentos metodológicos, têm-se o levantamento e apreciação de bibliografias sobre desenvolvimento econômico e transportes, com destaque aos portos e transporte marítimo. Estudos sobre circulação, fluidez territorial, competitividade, logística de Estado, logística privada, estratégias setoriais e outros são importantes para a interpretação dos transportes e da logística no atual estágio da acumulação capitalista que atinge o Brasil, juntamente com pesquisas em sites da internet, revistas, jornais, instituições públicas e privadas etc. Trabalhos de campo foram realizados para verificação das infraestruturas e dos gargalos existentes em diversos portos brasileiros (Santos/SP, Paranaguá/PR, Itapoá/SC, Itajaí/ SC, Navegantes/SC, Salvador/BA, Suape/PE etc.), além da aplicação de entrevistas destinadas aos responsáveis por diversas instituições, caso das Companhias Docas, Administrações Portuárias, Autoridades Portuárias e terminais privados. A coleta de dados e informações ocorreram em vários órgãos e sites, caso das Administrações Portuárias, Agência Nacional de Transportes Aquaviários (ANTAQ), Ministério do Desenvolvimento, Indústria e Comércio Exterior - Secretaria de Comércio Exterior (SECEX), Secretaria Nacional de Portos e outros. Quadros e mapa foram confeccionados a partir das informações e dos dados estatísticos obtidos, especialmente sobre os principais portos e terminais brasileiros.

O texto está estruturado em quatro partes, quais sejam: transporte marítimo e dinâmica econômica; o transporte de cabotagem e longo curso no Brasil; as reestruturações do setor portuário e marítimo: alguns apontamentos; e as modernizações setoriais no Brasil. Além disso, nas considerações finais são apresentadas algumas propostas para fomentar o sistema portuário brasileiro, articulando o planejamento estatal, os investimentos e a participação da iniciativa privada.

\section{Transporte marítimo e dinâmica econômica}

Os avanços ligados ao transporte marítimo (logística, normas, tributações, tecnologias de comunicação, informação e navegação etc.) permitem o escoamento de cargas em menos tempo e com maior segurança, por conseguinte, há baixo risco de perda e avaria nos produtos, prejuízo por parte dos produtores e atraso na entrega dos bens. A expansão do transporte marítimo, o aprimoramento da logística de estocagem e distribuição e a modernização dos navios cargueiros reduzem o tempo de rotação, os custos de circulação, favorecem a conquista de economias de escala, a especialização produtiva e a competitividade.

A expansão do transporte marítimo reduz o tempo gasto com a circulação das cargas no espaço, possibilitando a conquista de mercados distantes geograficamente (importações e exportações). A logística, por sua vez, permite atenuar os pontos de estrangulamento existentes no sistema portuário e marítimo que prejudicam a fluidez no escoamento, o cumprimento dos prazos de entrega e a rapidez na circulação do capital (Silveira, 2009). Infere-se, portanto, que o aprimoramento da logística por parte das empresas é mais rápido do que a melhoria da base material (infraestruturas de transportes).

O aumento da mobilidade do capital provoca mudanças na organização dos processos de produção e de troca em escala global. Os agentes econômicos realizam investimentos diversos em espaços que oferecem vantagens, como a construção de unidades industriais em regiões com adequadas condições infraestruturais (portos, hidrovias, rodovias, ferrovias, dutovias, rede elétrica, infovias etc.), incentivos tributários, mão de obra abundante e barata, entre outros, com o objetivo de redução dos custos e maximização do lucro. 
O transporte marítimo é parte integrante da formação econômica regional e nacional. Os portos e os terminais privados são importantes para a dinâmica macroeconômica e para o estabelecimento das relações de poder internas e externas (capital financeiro, burguesia industrial, latifundiários, agronegócio, oligopólios setoriais e outros). A recuperação da economia brasileira entre 2003 e 2013 intensificou a cabotagem, as exportações e as importações nacionais, gerando repercussões espaciais (impulso da atividade produtiva, geração de empregos e renda, melhoria relativa das infraestruturas de transportes e energia etc.).

O processo de desenvolvimento econômico, as trocas e a circulação do capital são influenciados pelos ciclos de crescimento e crise da economia nacional e internacional. A expansão do transporte marítimo gera repercussões positivas na produção agrícola e industrial, nos serviços, na mineração, na pecuária, no comércio exterior e nas redes e fluxos no espaço. Os pontos de estrangulamento setoriais, por sua vez, prejudicam a fluidez no território.

Como nos momentos de crise há queda no consumo, nos fluxos marítimos e nas trocas internacionais, é imprescindível a realização de investimentos infraestruturais por parte do Estado e da iniciativa privada (através de adequadas parcerias público-privadas PPPs), pois, dessa maneira, são estimulados diversos setores econômicos (indústrias, serviços, comércio e agropecuária) e são gerados empregos e renda. Os instrumentos de política econômica devem criar condições para amenizar os efeitos da recessão externa e interna (servindo como medidas anticíclicas), e retomar a atividade produtiva e o crescimento do mercado formal de trabalho (Rangel, 2005).

A experiência internacional, sobretudo dos países asiáticos, demonstra os resultados positivos provenientes das interações entre os investimentos em infraestruturas, a expansão industrial e o crescimento econômico. China, Coreia do Sul, Japão e outros executaram/executam programas de agregação de valor e tecnologia à produção e às exportações, fortes incentivos governamentais, atração de inversões (nacionais e estrangeiras), além de exigências de desempenho impostas pelo Estado às empresas. Na China, as elevadas taxas de poupança e investimento, a expansão do crédito, o aumento da produtividade das indústrias etc., conduzem a um expressivo crescimento da economia, mesmo diante da crise internacional (Belluzzo, 2017). O setor portuário é estratégico no projeto de desenvolvimento econômico chinês, com grande destaque internacional na movimentação de cargas, contêineres e navios (em 2015, sete dos dez principais portos do mundo foram da China, sendo liderado por Xangai - Portal Marítimo, 2017).

No caso do Brasil, a retomada do desenvolvimento depende da capacidade do Estado recuperar sua função de planejador e coordenador da política macroeconômica, valorizando investimentos maciços em infraestruturas e serviços públicos. Isto é, a saída para a crise interna não é a política neoliberal, mas sim um projeto nacional de desenvolvimento que permita retomar a geração de empregos, fomentar a distribuição de renda e arrefecer as desigualdades sociais e inter-regionais. Nesse sentido, o setor portuário e marítimo é estratégico para atender demandas corporativas, econômicas e sociais, bem como fomentar a economia nacional através dos investimentos públicos e privados em fixos, tecnologias, intermodalidade e outros.

Transformações no espaço, na sociedade e na economia ocorrem a partir dos investimentos públicos e privados, com impactos e mudanças em diversas escalas (local, regional e nacional). Inversões em infraestruturas e serviços públicos geram benefícios econômicos e sociais, além de alterações no território, fomentando, por conseguinte, o desenvolvimento. A construção naval também deve fazer parte da política industrial 
estratégica da União (como ocorreu nos governos Lula da Silva e Dilma Rousseff), pois é um dos segmentos produtivos que possui maior capacidade de gerar efeito multiplicador na economia.

A dinâmica do setor portuário e marítimo possui uma relação intrínseca com os ciclos econômicos e com o desenvolvimento nacional, pois quando aumentam os investimentos públicos e privados em infraestruturas e na modernização setorial, há incremento do emprego, da renda e do consumo, ou seja, surgem reflexos nos segmentos produtivos, no comércio e nos serviços. Ademais, em momentos de crescimento da economia nacional, tem-se uma elevação da demanda por circulação no território, estimulando o setor de transportes e armazenamento, especialmente as empresas transportadoras, os centros de distribuição (CDs), os terminais alfandegados, os operadores logísticos e outros.

\section{O transporte de cabotagem e longo curso no Brasil}

O fomento do comércio exterior brasileiro e a maior diversificação das parcerias comerciais (fluxos Sul-Sul) - principalmente entre 2003 e 2013 - geraram importantes reflexos no transporte marítimo e no setor portuário nacional, com aumento da demanda por inversões em infraestruturas, maior movimentação de cargas, contêineres e navios nos portos brasileiros, modernização (investimentos em instalações, equipamentos e softwares), mudanças normativas e tributárias, aprimoramento da logística e da gestão, entre outros. Os principais portos e terminais privados do Brasil (Santos/SP, Rio de Janeiro/RJ, Paranaguá/PR, Rio Grande/RS, Itajaí/SC, Itapoá/SC, Navegantes/SC, Vitória/ES, Ponta da Madeira/MA, Suape/PE, Pecém/CE, Salvador/BA, Itaqui/MA, Manaus/AM etc.) possuem muitas linhas entre si (navegação de cabotagem), e destes com os mais importantes portos do mundo, como Xangai (China), Cingapura e Roterdã (Holanda) - transporte de longo curso.

\section{A cabotagem brasileira}

O transporte marítimo de cabotagem articula portos localizados em um mesmo país, todavia, no Brasil ainda é incipiente esta modalidade de transporte em comparação ao modal rodoviário. A grande dimensão territorial brasileira e sua extensa costa litorânea (mais de 8 mil quilômetros) criam condições propícias à cabotagem, porém há um predomínio exacerbado do transporte de cargas por caminhões (ainda que este seja importante para garantir o sistema "porta a porta"). A cabotagem no Brasil é realizada, principalmente, entre portos distantes geograficamente, caso, por exemplo, da articulação entre Santos/SP e Suape/PE, Rio Grande/RS e Salvador/BA etc.

Principalmente nas décadas de 1950, 1960 e 1970 o transporte de cabotagem era mantido com base na reserva de mercado e na existência de empresas estatais e privadas operando no setor, fato que criava demanda na indústria naval nacional. Lloyd Brasileiro e Costeira (estatais), juntamente com a Aliança e a Netumar (cabotagem e longo curso) - estas duas últimas privadas - eram as principais e atuavam sob o regime de concessão. Entretanto, na década de 1990, a cabotagem foi desmantelada com a desregulamentação do setor e a política neoliberal (governos de Fernando Collor e Fernando Henrique Cardoso).

Fomentar a cabotagem no Brasil é importante para racionalizar o setor de transportes no país, mitigar o Custo Brasil, aumentar a competitividade dos produtos nacionais, reduzir o preço final dos bens, arrefecer os congestionamentos de caminhões nos acessos dos principais portos marítimos brasileiros, além de impulsionar 
as redes, os fluxos de mercadorias e as interações espaciais. Ademais, a expansão da cabotagem gera demanda na indústria naval (construção de navios e embarcações) e nos armadores nacionais, contribuindo, assim, com a geração de empregos e renda. Nesse sentido, foi criado na última década o Projeto de Incentivo à Cabotagem (PIC) para alavancar o setor, contudo, este acabou não gerando resultados expressivos.

Como estratégia para fomentar a cabotagem no Brasil, é importante viabilizar o carreamento de recursos ociosos para o setor, bem como aplicar o modelo ideal de concessão de serviços públicos à iniciativa privada, ou seja, de acordo com a proposta de Ignácio Rangel (Projeto de Lei 2.569/89) e diferentemente da lei geral de concessões de serviços públicos (Lei 8.987/95) - Lei Fernando Henrique Cardoso. A transferência de recursos ociosos para a cabotagem e o longo curso (antiociosos) deve ser estimulada a partir de uma estrutura legal e de um mecanismo de intermediação financeira que estimule investimentos no setor, evitando-se que tais recursos sejam destinados ao sistema financeiro, ao mercado especulativo e a segmentos superinvestidos (Rangel, 2005). Garantir a reserva de mercado, aumentar os financiamentos e a demanda (a partir, por exemplo, da criação de empresas estatais e privadas de cabotagem), incentivos fiscais setoriais, mudanças normativas e outros, são ações que contribuem para alavancar a cabotagem no país.

A concessão de serviços públicos à iniciativa privada deve estar ligada à ideia de desenvolvimento econômico nacional a partir do Estado planejador e interventor (poder concedente e credor hipotecário). Adequadas concessões de atividades ligadas ao setor portuário e marítimo, como transporte, transbordo, armazenamento etc., são importantes para o fomento da economia regional e nacional. Dessa maneira, são gerados empregos e renda no setor de transportes, na construção civil (terminais intermodais), nas indústrias de base (metalúrgicas, siderúrgicas, petroquímicas etc.) e nas indústrias de bens de capital (máquinas e equipamentos) (Rangel, 2005).

A concessão de serviços públicos à iniciativa privada não significa isentar o Estado de suas funções e responsabilidades políticas, administrativas, econômicas, financeiras e de planejamento, isto é, não representa o modelo liberal, muito pelo contrário, cabe ao poder público as seguintes funções e poderes: dizer como e onde investir, quais tarifas devem ser cobradas, estabelecer limites de preços, impor metas e prazos a serem cumpridos, fiscalização das ações e medidas adotadas pelo concessionário, poder concedente e credor hipotecário, entre outros. A proposta rangeliana para as concessões de serviços públicos à iniciativa privada é pautada em um poder público capaz de impor e cobrar das concessionárias os objetivos estabelecidos em contrato. No entanto, a lei geral que regulamentou as concessões de serviços públicos no Brasil (Lei 8.987/95) é contrária aos interesses nacionais e pautada no Estado-mínimo. Reflexos desse modelo equivocado estão nas telecomunicações, ferrovias, rodovias, portos e outros equipamentos e serviços de utilidade pública no território brasileiro.

No que tange aos portos que mais atuam na cabotagem brasileira, têm-se: Santos/ SP, Vila Conde/PA, Suape/PE, Itaqui/MA, Fortaleza/CE, Pecém/CE, Paranaguá/PR, Rio Grande/RS e Belém/PA. Todavia, as quantidades e o valor agregado movimentados não são expressivos, pois prevalecem os fluxos de importação e exportação no sistema portuário nacional (no geral, $90 \%$ das cargas marítimas são de longo curso e apenas 10\% de cabotagem - Antaq, 2017). Em relação aos Terminais de Uso Privativo (TUPs), os sete principais em movimentação são: Almirante Barroso (São Sebastião/SP), Almirante Maximiliano Fonseca (Angra dos Reis/RJ), Madre de Deus/BA, Trombetas (Oriximiná/PA), Almirante Tamandaré (Rio de Janeiro/RJ), Alumar (São Luís/MA) e Transpetro (São Francisco do Sul/SC). Conjuntamente 
movimentaram $60 \%$ da tonelagem da cabotagem brasileira em 2014. Diante disso, evidencia-se que, apesar do Brasil possuir muitos portos/terminais e uma extensa costa litorânea, as operações ligadas à cabotagem são concentradas em apenas alguns pontos do território brasileiro (Fonseca, 2015).

Há um predomínio dos fluxos de petróleo e derivados pela cabotagem brasileira, que representam $70 \%$ da circulação total de mercadorias, e os minérios $15 \%$. Assim, infere-se que esses dois grupos juntos representaram 85\% do total em 2014. No que tange à movimentação de contêineres, estes indicam apenas $6 \%$, o que elucida a necessidade de expandir os modais ferroviário e hidroviário no segmento de carga geral no Brasil. Isso está relacionado não somente à fluidez territorial, mas também é uma estratégia para estimular a produção de bens de média e alta tecnologia no país.

Petróleo e derivados se destacam nos fluxos de cabotagem, com grande participação da Petrobras e da Transpetro no setor. Ademais, esses produtos também são escoados por dutovias, que interligam os fixos portuários às refinarias e centros de distribuição, através de uma rede extensa, articulando, principalmente, o Sul, o Sudeste e o CentroOeste do país. Apenas seis empresas possuem capacidades acima de 100 mil toneladas de movimentação, quais sejam: Petrobras, Norsul, Elcano, Aliança, Log-in e Mercosul Line (Fonseca, 2012).

A cabotagem brasileira (Quadro 1) é uma modalidade de transporte que precisa de expansão, pois pode se beneficiar das características físicas e demográficas do território brasileiro, sobretudo pelo fato do país possuir uma costa extensa e uma concentração populacional próxima do litoral. É um modal que foi desfavorecido pelas políticas públicas, especialmente a partir da década de 1950, já que estas valorizaram o modal rodoviário. Além disso, atualmente a cabotagem serve, principalmente, às operações do circuito produtivo do petróleo e derivados - a Petrobras e a Transpetro movimentam mais de $40 \%$ da tonelagem da cabotagem brasileira, e ainda influenciam as políticas estatais para o modal hidroviário e para a indústria naval (Fonseca, 2015; Antaq, 2017).

Exceto a pequena variação de 2015 em relação a 2014, o transporte de cabotagem no Brasil cresceu ao longo do período, com destaque ao transporte de granéis líquidos (Quadro 1). O transporte de cabotagem apresentou expansão relativa nos últimos anos, porém a utilização do modal ainda é reduzida no país. A partir da logística de Estado, o poder público deveria realizar investimentos em portos estratégicos destinados à cabotagem, como forma de estimular o setor (capacidade antiociosa). Essa estratégia é adotada nos Estados Unidos e no Canadá há décadas e, mais recentemente, na China, favorecendo as conexões inter-regionais e o setor produtivo.

Quadro 1. Transporte de cabotagem no Brasil (2011-2016) (milhões de toneladas). Fonte: Agência Nacional de Transportes Aquaviários (ANTAQ), 2017.

\begin{tabular}{|l|c|c|c|c|}
\hline Anos & Granéis sólidos & Granéis líquidos & Carga geral & Total \\
\hline 2011 & 32,5 & 139,6 & 10,9 & 183,0 \\
\hline 2012 & 33,9 & 141,9 & 28,5 & 204,3 \\
\hline 2013 & 34,6 & 142,7 & 33,2 & 210,5 \\
\hline 2014 & 35,7 & 143,0 & 32,4 & 211,1 \\
\hline 2015 & 34,2 & 142,8 & 33,7 & 210,7 \\
\hline 2016 & 36,0 & 143,2 & 33,2 & 212,4 \\
\hline
\end{tabular}

Alguns portos das macrorregiões Norte e Nordeste - como Suape/PE, Itaqui/MA, Manaus/AM e Vila do Conde/PA - destacam-se na navegação de cabotagem, em especial, no escoamento de granéis líquidos (combustíveis, óleos, fertilizantes etc.) 
e carga geral (artigos industriais da Zona Franca de Manaus/AM, veículos, bobinas de aço, manufaturas e outros). Entre 2005 e 2015, o transporte de cargas por cabotagem no complexo de Suape/PE evoluiu 368\%. Houve crescimento na movimentação de 2,8 milhões de toneladas em 2005, para 13,3 milhões de toneladas em 2015. O avanço elevou o porto pernambucano para a liderança nacional nesse tipo de operação.

O transporte marítimo pela costa brasileira é relevante para reduzir o Custo Brasil em transportes e fomentar as redes, os fluxos de cargas, as interações espaciais e o crescimento econômico. Este modal é sensível à dinâmica econômica nacional e carece de um planejamento estratégico - juntamente ao modal ferroviário e à intermodalidade - para reequilibrar a matriz de transportes brasileira.

Os principais fatores que prejudicam o avanço da cabotagem no Brasil são: a questão cultural ligada ao modal rodoviário, rodovias pedagiadas em condições adequadas (são vantajosas às indústrias produtoras de bens de alto valor agregado), óleo diesel subsidiado, possibilidade do sistema "porta a porta" pelo caminhão, as empresas de navegação e os operadores de terminais preferem investir, muitas vezes, no longo curso em detrimento da cabotagem (mais lucrativo) e outros.

A expansão da cabotagem, do longo curso, da indústria naval e dos investimentos em infraestruturas portuárias, com aquisição de insumos e equipamentos nacionais, é uma importante estratégia para alavancar a produção brasileira e, consequentemente, o desenvolvimento econômico nacional (Rangel, 2005). Nesse sentido, é necessário estimular a cabotagem no país, com base no crédito a juros baixos, nos subsídios estatais ao setor, na reserva de mercado, na adequação do sistema normativo etc.

Não existem terminais especializados no transporte de cabotagem nos principais portos do Brasil, caso, por exemplo, de Santos/SP, Paranaguá/PR, Itajaí/SC, Rio Grande/RS etc., já que há, em geral, uma preferência pelo transporte de longo curso, em decorrência de algumas vantagens, tais como: a possibilidade dos armadores realizarem mais escalas em portos de diferentes países, cargas de retorno (navios carregados com produtos de importação), os fretes se tornam mais baratos (devido às maiores distâncias percorridas), utilização de navios maiores e com grande capacidade de escoamento de cargas, entre outros.

\section{O transporte marítimo de longo curso no Brasil}

O transporte marítimo de longo curso é aquele realizado entre dois ou mais portos de diferentes países. O tráfego marítimo mundial é dividido por tipo de carga, ou seja, em granéis líquidos, granéis sólidos e carga geral. Algumas poucas mercadorias representam $60 \%$ da tonelagem total transportada no comércio internacional, caso do petróleo e seus derivados, minérios, grãos, farelos e carvão (Antaq, 2017).

O sistema marítimo paulista (principalmente o Porto de Santos/SP) se destaca na movimentação de bens industrializados e contêineres (maior valor agregado), sendo um ponto nodal que atende à demanda, sobretudo, do estado de São Paulo e do CentroOeste do país. Os fluxos hidroviários são um reflexo da dinâmica econômica regional e nacional, nesse sentido, há uma concentração tanto dos fixos quanto dos fluxos de mercadorias no Centro-Sul do país (Quadro 2). 
Quadro 2. Principais portos/terminais brasileiros na movimentação de cargas de longo curso em 2016 (milhões de toneladas). Fonte: Agência Nacional de Transportes Aquaviários (ANTAQ), 2017.

\begin{tabular}{|l|c|c|}
\hline Ranking & Portos/terminais & Quantidades \\
\hline 1 & Ponta da Madeira/MA & 146,6 \\
\hline 2 & Tubarão/ES & 106,6 \\
\hline 3 & Santos/SP & 86,1 \\
\hline 4 & Itaguaí/RJ & 57,7 \\
\hline 5 & Terminal da llha Guaíba (TIG)/RJ & 46,1 \\
\hline 6 & Paranaguá/PR & 36,9 \\
\hline 7 & Terminal da Baía de llha Grande (TEBIG)/RJ & 20,1 \\
\hline 8 & Rio Grande/RS & 18,1 \\
\hline 9 & Porto do Açu/RJ & 15,9 \\
\hline
\end{tabular}

Há uma grande concentração econômica e dos fluxos marítimos no Sul e no Sudeste do país (quadro 2), consequentemente, tem-se uma significativa demanda pelos portos. Estes representam mais de 70\% de todo comércio exterior brasileiro e, no caso das exportações de produtos industrializados, são responsáveis por $85 \%$ do total nacional (Antaq, 2017). No que tange ao transporte de longo curso (predominante no país), verifica-se um crescimento relativo, com destaque aos portos/terminais mais modernos (quadro 3).

Quadro 3. Transporte de cargas no longo curso no Brasil (2011-2016) (milhões de toneladas). Fonte: Agência Nacional de Transportes Aquaviários (ANTAQ), 2017.

\begin{tabular}{|c|c|c|c|}
\hline Anos & Longo curso & Exportação & Importação \\
\hline 2011 & 657,5 & 514,6 & 142,9 \\
\hline 2012 & 670,5 & 525,7 & 144,8 \\
\hline 2013 & 684,2 & 531,7 & 152,5 \\
\hline 2014 & 713,6 & 552,1 & 161,5 \\
\hline 2015 & 754,1 & 610,8 & 143,3 \\
\hline 2016 & 741,5 & 605,9 & 135,6 \\
\hline
\end{tabular}

Houve aumento na movimentação de mercadorias no longo curso nos últimos anos, com pequena redução em 2016 em comparação a 2015 (Quadro 3), devido, sobretudo, à queda da demanda brasileira (empresas e consumo humano). Esse tipo de transporte é responsável por grande parte do comércio exterior brasileiro (exportações e importações). Nesse contexto, destacam-se os granéis sólidos como os principais produtos de exportação do país (Quadros 4 e 5).

Quadro 4. Movimentação e participação por tipo de carga nos portos/terminais do Brasil, 2016. Fonte: Agência Nacional de Transportes Aquaviários (ANTAQ), 2017.

\begin{tabular}{|l|c|c|c|}
\hline \multicolumn{2}{|c|}{ Movimentação (milhões de toneladas) } & \multicolumn{2}{c|}{ Participação (porcentagem) } \\
\hline Granel sólido & 569 & Granel sólido & 77 \\
\hline Granel líquido & 65 & Granel líquido & 9 \\
\hline Carga geral & 32 & Carga geral & 4 \\
\hline Contêiner & 77 & Contêiner & 10 \\
\hline
\end{tabular}

Quadro 5. Principais portos/terminais por tipo de carga no Brasil (milhões de toneladas), 2016. Fonte: Agência Nacional de Transportes Aquaviários (ANTAQ), 2017.

\begin{tabular}{|l|c|c|c|}
\hline \multicolumn{2}{|c|}{ Granel sólido } & \multicolumn{2}{c|}{ Granel líquido } \\
\hline \multicolumn{1}{|c|}{ Portos/terminais } & Quantidades & Portos/terminais & Quantidades \\
\hline Itaguaí/RJ & 55,5 & Suape/PE & 17,3 \\
\hline Santos/SP & 50,0 & Santos/SP & 12,1 \\
\hline Paranaguá/PR & 28,2 & Itaqui/MA & 6,2 \\
\hline Vila do Conde/PA & 11,1 & Aratu/BA & 4,4 \\
\hline Rio Grande/RS & 9,9 & Rio Grande/RS & 3,7 \\
\hline
\end{tabular}




\begin{tabular}{|l|c|c|c|}
\hline \multicolumn{2}{|c|}{ Contêiner } & \multicolumn{2}{c|}{ Carga geral solta } \\
\hline \multicolumn{1}{|c|}{ Portos/terminais } & Quantidades & Portos/terminais & Quantidades \\
\hline Santos/SP & 32,0 & Rio Grande/RS & 3,3 \\
\hline Portonave (Navegantes/SC) & 9,7 & Santos/SP & 2,9 \\
\hline Paranaguá/PR & 8,2 & São Francisco do Sul/SC & 2,3 \\
\hline Rio Grande/RS & 7,3 & Itaqui/MA & 1,5 \\
\hline Embraport (Santos/SP) & 6,7 & Paranaguá/PR & 1,3 \\
\hline
\end{tabular}

As vendas externas do Brasil são concentradas nas commodities, destacando-se o comércio com a China, os Estados Unidos, a União Europeia e o Mercosul. Ainda que tais produtos do agronegócio envolvam muitas pesquisas científicas, tecnologias, melhoramento de sementes, patentes etc., é importante o Brasil agregar mais valor às exportações (impulsionar as vendas externas de bens de média e alta tecnologia), como estratégia para fomentar o efeito multiplicador interno.

O Porto de Santos/SP se destaca na movimentação de bens industriais e contêineres no Brasil, sendo seguido por outros portos e terminais privados do Sul do país (quadros 4 e 5). Esses complexos, em geral, são mais modernos e mais competitivos do que os portos do Nordeste e do Norte, sendo assim atrativos ao grande capital privado nacional e internacional. As vantagens são infraestruturais, tecnológicas, organizacionais, logísticas, fiscais, proximidade com os principais mercados consumidores do país, concentração industrial, demográfica e da circulação, entre outros.

Há diferenciações no sistema portuário das unidades federativas brasileiras, quais sejam: em São Paulo, no Paraná, no Rio Grande do Sul, em Pernambuco e no Ceará os fluxos se concentram basicamente em um único porto (Santos/SP, Paranaguá/PR, Rio Grande/RS, Suape/PE e Pecém/CE), já no Rio de Janeiro, na Bahia e em Santa Catarina há uma maior desconcentração portuária (Rio de Janeiro/RJ, Itaguaí/RJ, Angra dos Reis/RJ, Salvador/BA, Aratu/BA, São Francisco do Sul/SC, Itapoá/SC, Itajaí/SC, Navegantes/SC, Imbituba/SC etc.) - Figuras 1, 2 e 3.

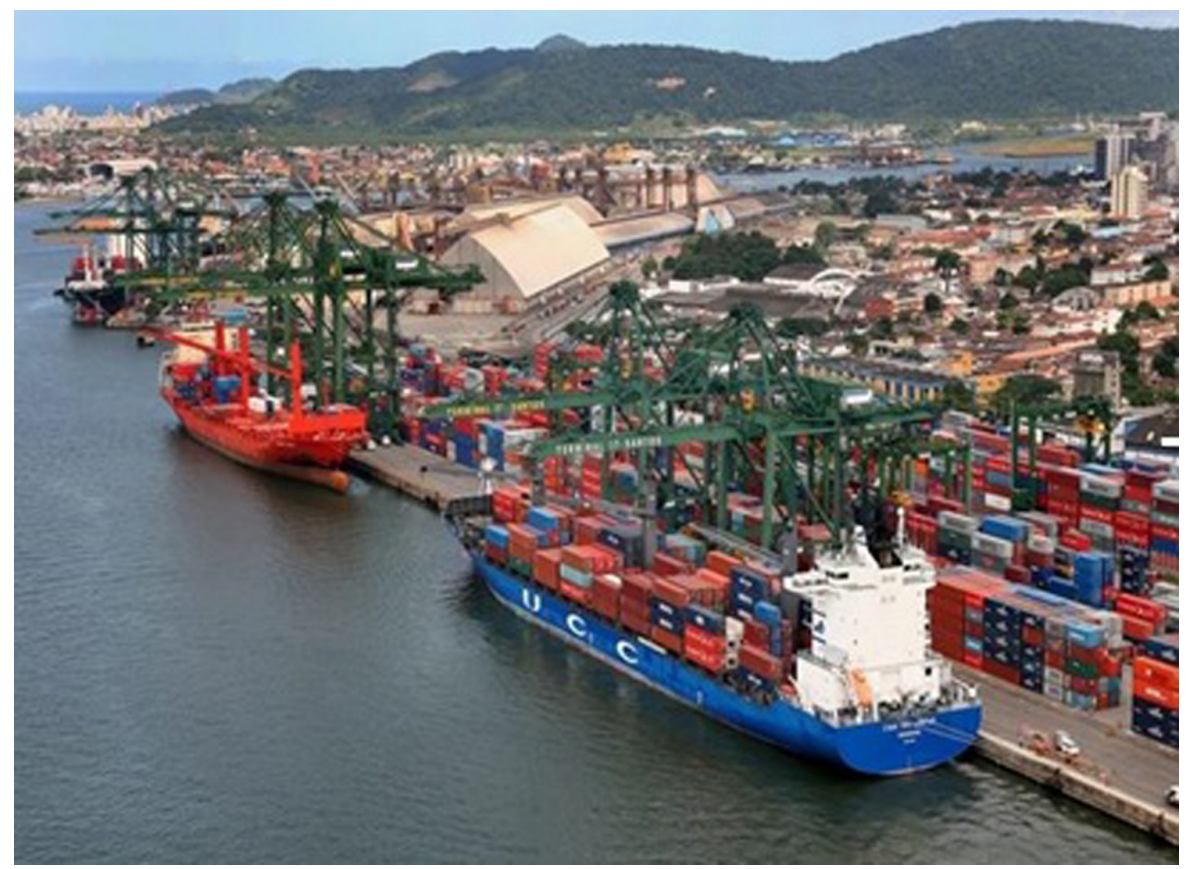

Figura 1. Porto de Santos/SP. Fonte: Companhia Docas do Estado de São Paulo (CODESP), 2017. 


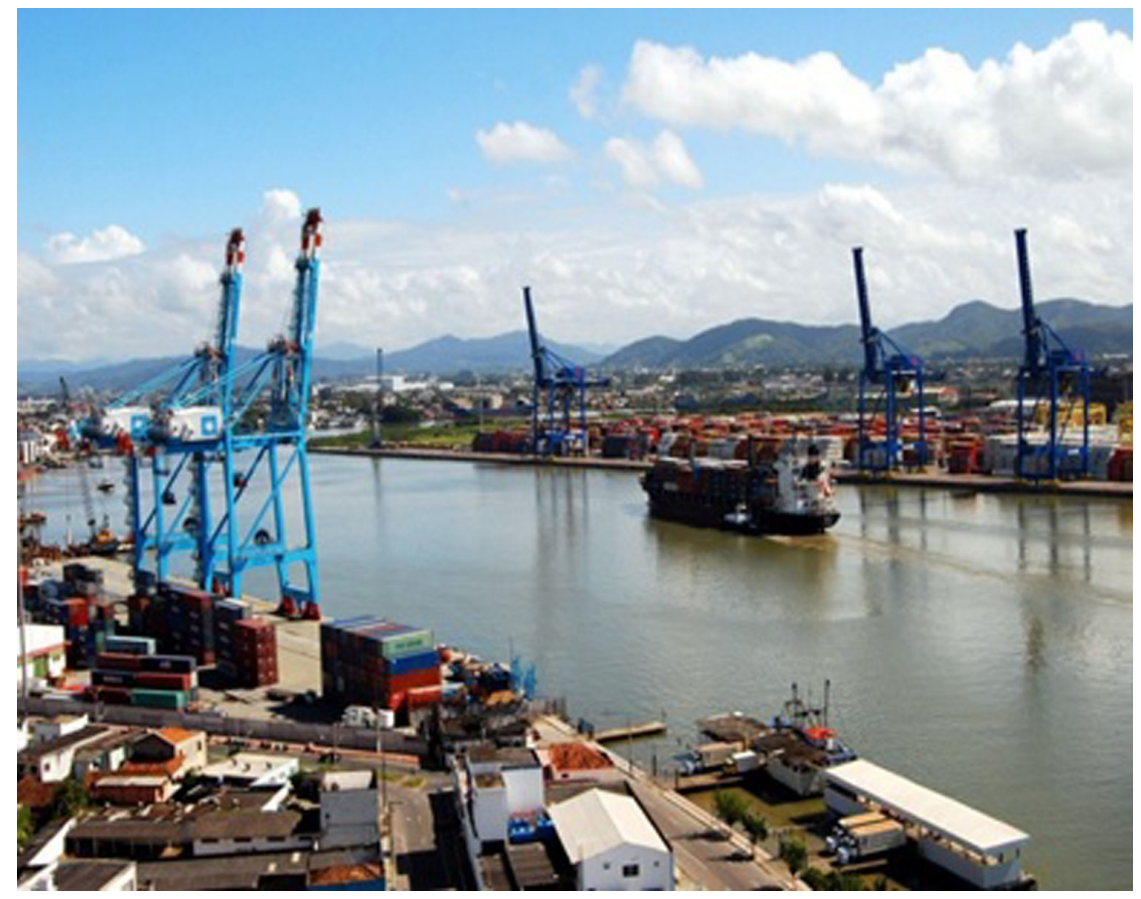

Figura 2. Complexo portuário de Itajaí-Navegantes/SC. Fonte: Autoridade Portuária de Itajaí, 2017.

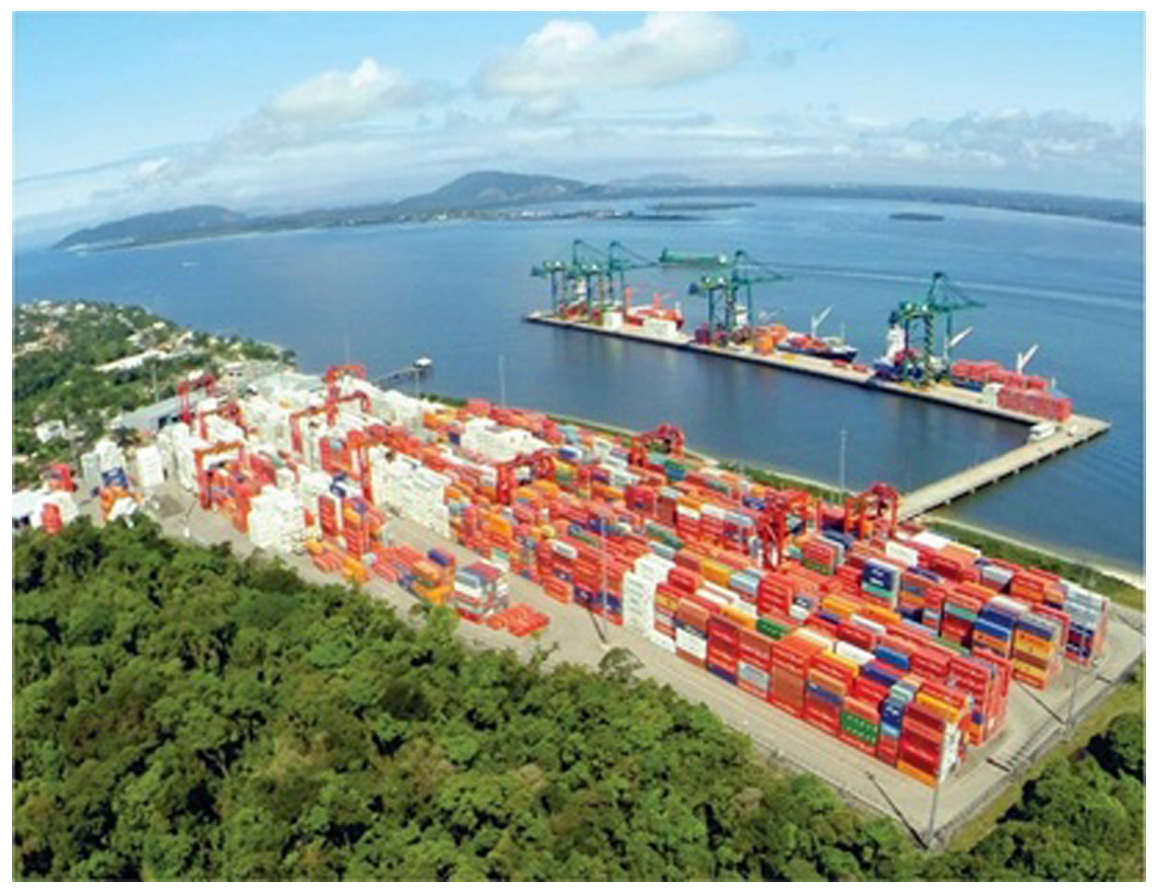

Figura 3. Terminal de Itapoá/SC. Fonte: Terminal de Itapoá, 2017.

De acordo com Rangel (2005), o Estado - com base no planejamento - deve criar condições para o espraiamento da produção industrial. Assim, precisa aplicar uma determinada quantidade de recursos nos espaços periféricos para melhorar suas condições materiais (rodovias, ferrovias, dutovias, portos, aeroportos, energia elétrica, saneamento básico etc.). As inversões estatais geram demanda e, a partir dos investimentos privados, potencializa-se a dinâmica produtiva, comercial e os serviços. O setor 
marítimo, por sua vez, também será estimulado, com incremento das inovações, das mercadorias movimentadas, dos fluxos de navios cargueiros, cabotagem, exportações e importações (Quadro 6).

Quadro 6. Participação regional na movimentação de cargas hidroviárias (fluviais e marítimas), 2016. Fonte: Agência Nacional de Transportes Aquaviários (ANTAQ), 2017.

\begin{tabular}{|l|c|c|}
\hline \multirow{2}{*}{ Macrorregiões } & \multicolumn{2}{|c|}{ Quantidades } \\
\cline { 2 - 3 } & Milhões de toneladas & Porcentagem \\
\hline Sudeste & 496,0 & 50 \\
\hline Nordeste & 270,0 & 27 \\
\hline Sul & 142,4 & 14 \\
\hline Norte & 86,0 & 9 \\
\hline Centro-Oeste & 3,7 & 0,1 \\
\hline
\end{tabular}

Há uma grande concentração dos fluxos aquaviários na região Sudeste, o que elucida sua relevância econômica no país (Quadro 6). Com o Programa de Aceleração do Crescimento (PAC) e, mais precisamente o PAC-portos, buscou-se melhorar as operações portuárias e marítimas. Tais investimentos foram importantes especialmente para a região Nordeste (ampliação dos portos de Pecém/CE e Suape/PE, duplicação de trechos da BR-101, construção de molhes etc.) - figuras 4, 5 e 6 . Todavia, as inversões foram/são insuficientes e as obras públicas morosas e muitas ainda incompletas. É importante, por exemplo, que portos menores também recebam inversões públicas e privadas, visando à atração de cargas (granéis sólidos, granéis líquidos e carga geral). $\mathrm{O}$ desenvolvimento regional depende também da expansão do sistema portuário, gerando reflexos no emprego, na renda e no consumo internamente.

Na última década foram realizados vários programas, políticas e ações do Estado brasileiro ligados ao setor portuário e de infraestrutura, como o Programa de Aceleração do Crescimento (PAC-portos); BNDES Finem - Infraestrutura Logística; BNDES Finame; Fundo da Marinha Mercante (FMM); Regime Especial de Incentivos para o Desenvolvimento da Infraestrutura (Reidi); Plano de Investimento em Logística (PIL-Portos); Regime Tributário para Incentivo à Modernização e à Ampliação da Estrutura Portuária (Reporto); Plano Nacional de Logística Portuária (PNLP); Plano Nacional de Logística Integrada (PNLI); Programa de Parcerias de Investimentos (PPI); Corredores Logísticos Estratégicos: Complexo de Soja e Milho; e Programa Avançar. Além disso, destacam-se alguns incentivos fiscais concedidos pela União, estados e municípios no setor portuário, caso do Imposto sobre Circulação de Mercadorias e Serviços (ICMS), do Imposto sobre Serviços (ISS) e outros, intensificando a competição setorial no Brasil, especialmente na movimentação de contêineres (como exemplos, têm-se os terminais de Itapoá, Navegantes, Itajaí e Imbituba, em Santa Catarina).

No que tange aos investimentos privados e públicos (governo federal) em infraestruturas de transportes no Brasil (rodovias, ferrovias, portos e aeroportos), estes aumentaram de $R \$ 9,1$ bilhões em 2003 para $R \$ 31,6$ bilhões em 2015. Ficaram relativamente estabilizados entre 2010 e 2014, com aplicação média anual de R \$32,1 bilhões. Contudo, foram reduzidos em 2015, com investimentos totais de $\mathrm{R} \$ 28,2$ bilhões. As inversões privadas, em grande medida por exigências dos contratos de concessão, ainda cresceram um pouco em 2015 em relação ao ano anterior, elevando de $\mathrm{R} \$ 18,0$ bilhões para $\mathrm{R} \$ 18,4$ bilhões. Em 2007 (com o início das obras do PAC), foram investidos R $\$ 13,4$ bilhões em infraestruturas de transportes e, em 2017, as inversões totalizaram R\$14,1 bilhões no Brasil (Ipea, 2018). Isso mostra que, no atual contexto de política econômica neoliberal e ajuste fiscal, os recursos aplicados em fixos são reduzidos, prejudicando a retomada do crescimento econômico brasileiro. 


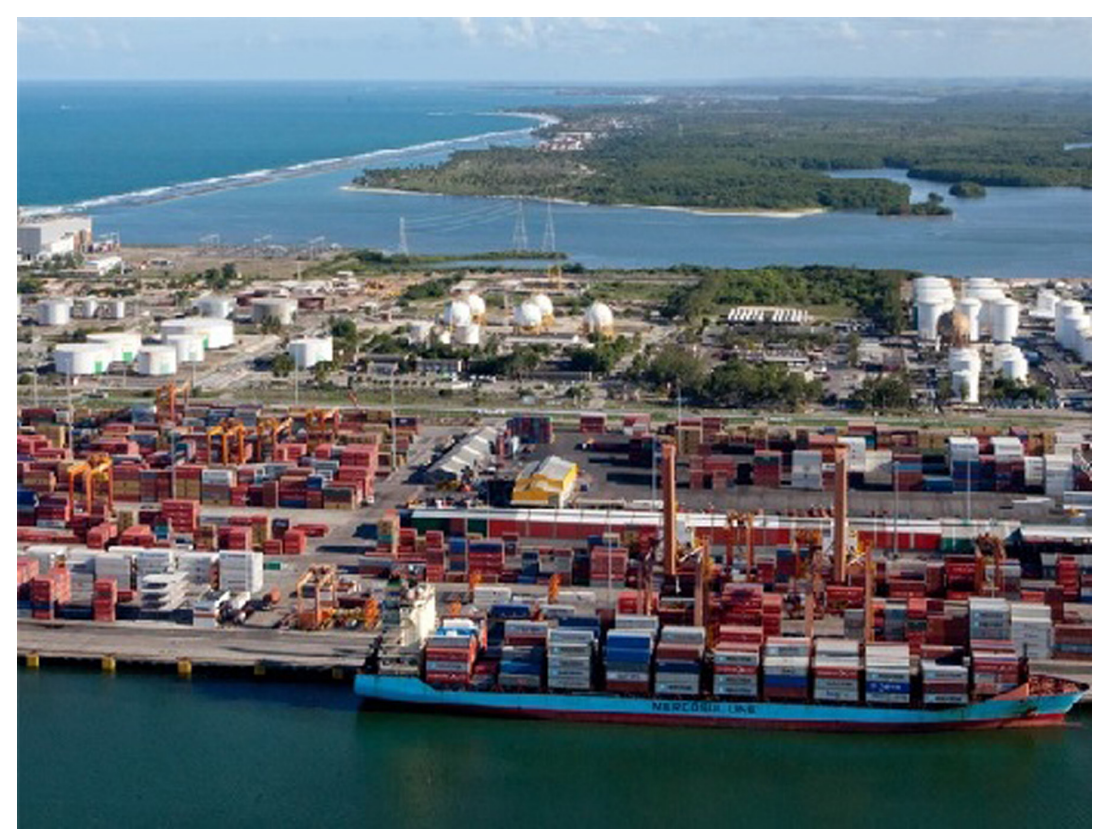

Figura 4. Complexo Portuário de Suape/PE, 2017. Fonte: Porto de Suape/PE, 2017.

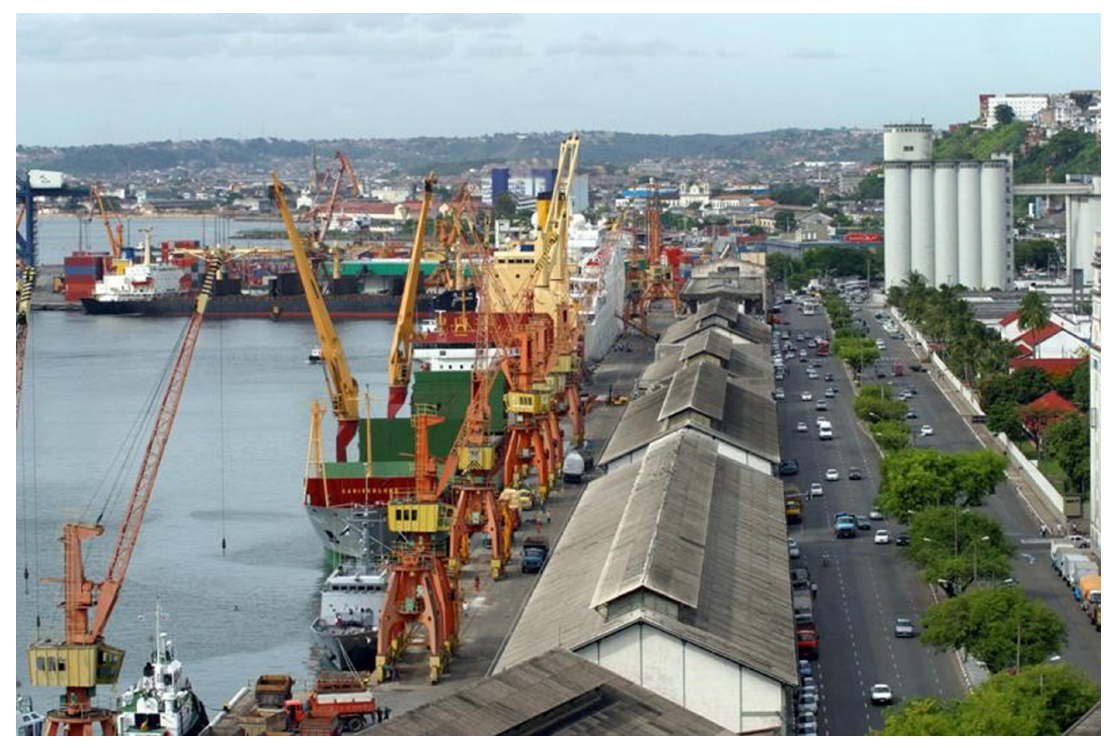

Figura 5. Porto de Salvador/BA, 2017. Fonte: Companhia Docas do Estado da Bahia (CODEBA), 2017. 


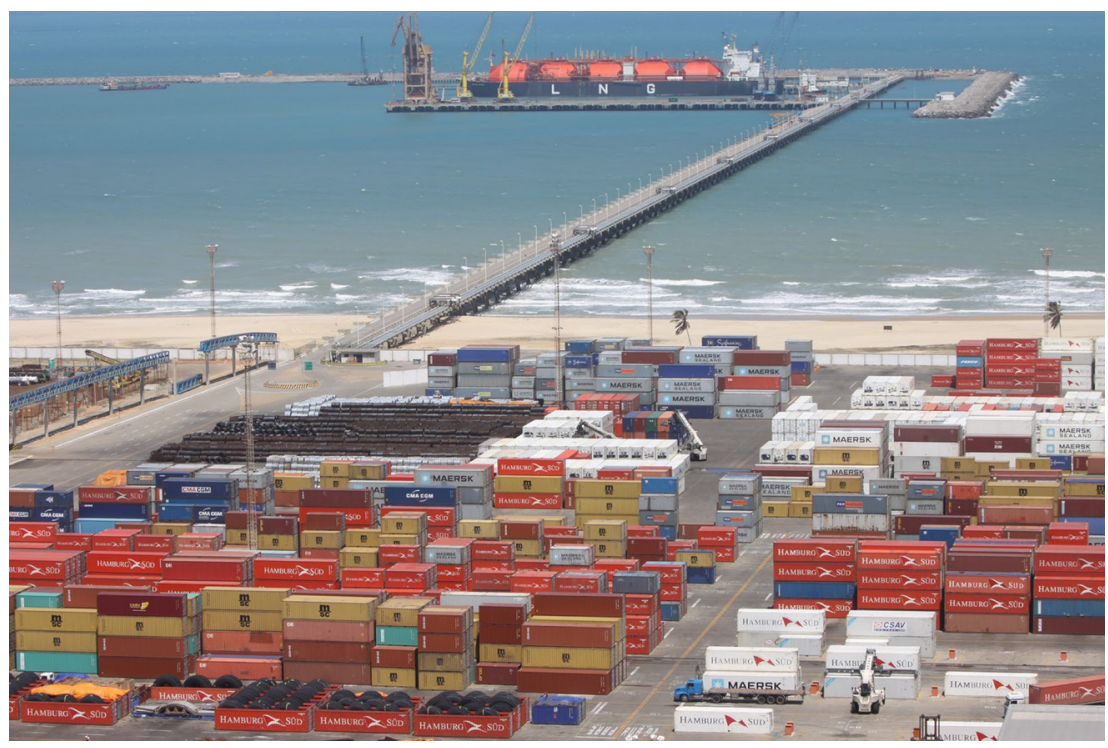

Figura 6. Porto de Pecém/CE, 2017. Fonte: Companhia de Integração Portuária do Ceará (CEARÁPORTOS), 2017

O setor portuário brasileiro registrou um aumento de $8,3 \%$ na movimentação total de cargas em 2017, em comparação a 2016, (totalizando 1,08 bilhão de toneladas). No que tange aos contêineres, houve elevação da tonelagem e dos TEUs (medida equivalente a 20 pés), sendo movimentados 106,2 milhões de toneladas (valor $6,1 \%$ superior ao registrado em 2016) e transportadas em 9,3 milhões de TEUs (aumento de 5,7\%). A carga que apresentou maior incremento $(10,3 \%)$ foi o granel sólido, com escoamento total de 695,4 milhões de toneladas em 2017. Milho e soja apresentaram crescimento de $71,8 \%$ e de $31,5 \%$, respectivamente, na comparação 2017/2016. Já o granel líquido registrou movimentação de 230,2 milhões de toneladas em 2017 - um aumento de $3,8 \%$ na comparação com o ano anterior. Os terminais de uso privado (TUPs) movimentaram 721,6 milhões de toneladas em 2017. Em 2016, a movimentação foi de 660 milhões de toneladas, o que representa um incremento de 9,3\%. Os portos públicos apresentaram crescimento de 6,3\%, registrando uma movimentação de 364,5 milhões de toneladas (Antaq, 2018).

Em relação aos tipos de navegação, as de longo curso apresentaram um aumento de 8\%, ficando responsáveis pela movimentação de 803,3 milhões de toneladas. A cabotagem transportou 221,8 milhões de toneladas em 2017, sendo 3,8\% maior do que a registrada em 2016. O transporte hidroviário interior, por sua vez, apresentou crescimento de 37,8\% em 2017 (57,3 milhões de toneladas) (Antaq, 2018). Diante desses dados, infere-se que, apesar da recessão interna, fatores como a reestruturação produtiva, a modernização portuária, as mudanças normativas e tributárias, a otimização das estratégias logísticas, a expansão de portos secos, Centros Logísticos Industriais Aduaneiros (CLIAs) e terminais alfandegados no território nacional (especialmente no CentroSul), entre outros, permitiram o incremento dos fluxos de cargas no sistema portuário e marítimo brasileiro. Tais reflexos também estão ocorrendo em portos do Norte e Nordeste do país, como o crescimento da cabotagem e do longo curso em Pecém/CE e Suape/PE, o aumento das exportações de soja por Itaqui/MA, fluxos de alimentos, combustíveis, grãos e bens industriais por Manaus/AM etc.

No que tange ao setor produtivo voltado ao mercado internacional, sobretudo as agroindústrias e indústrias, este utiliza os portos com maior capacidade de movimentação, como Santos/SP, Paranaguá/PR e Rio Grande/RS, além de outros das regiões Nordeste e Norte que crescem em movimentação, caso de Itaqui/MA, Pecém/CE, Manaus/AM, Santarém/PA e 
Suape/PE. Os estados de Mato Grosso, Mato Grosso do Sul e Goiás utilizam o complexo portuário santista entre 50\% e 60\% da movimentação total de suas cargas de importação e exportação, enquanto Paranaguá/PR tem uma participação entre 20\% e 30\%. Para as empresas exportadoras e importadoras (localizadas em estados litorâneos), os portos e terminais mais importantes, em geral, são aqueles dentro do próprio estado ou em unidades federativas vizinhas/próximas (Coutinho et al., 2013). Nos estados costeiros, a concentração da movimentação de suas próprias mercadorias é elevada (entre 70\% e 90\% em alguns casos), como São Paulo, Paraná, Santa Catarina, Rio Grande do Sul, Bahia e Pernambuco, entretanto, Sergipe, por exemplo, utiliza portos de outros estados para movimentar parte de suas cargas, com destaque aos complexos de Salvador/BA e Suape/PE. Isso é resultado dos reduzidos investimentos e da falta de modernização do Terminal Marítimo Inácio Barbosa (TMIB).

As principais empresas que utilizam o sistema portuário brasileiro são as multinacionais estrangeiras. Em 2015, Cargill Agrícola, Bunge Alimentos, Brasil Foods, Braskem, Nidera Sementes, Coamo, Bianchini, Archer Daniels Midland (ADM), Louis Dreyfus, General Motors, além de outras montadoras de veículos, destacaram-se na movimentação de mercadorias nos portos/terminais do Sul do país e no complexo santista. No Porto de Suape/PE (um dos principais da região Nordeste), além do agronegócio, cresceu a participação de empresas como a Bosch, Bic, FCA (Jeep e Fiat), Volkswagen, Toyota e General Motors na movimentação de cargas. A Vale do Rio Doce tem relevância em relação aos fluxos de minérios voltados ao mercado externo (sobretudo para a Ásia), utilizando terminais da própria empresa, como Ponta da Madeira/MA, Tubarão/ES, Itaguaí/RJ, Ilha Guaíba/RJ e Gregório Curvo (Corumbá/ MS - Rio Paraguai). Apesar da grande concentração da produção e da circulação no CentroSul do país, o capital produtivo passou a utilizar, de maneira mais intensa na última década, outros portos, principalmente para exportação de seus produtos, caso de Itaqui/MA (grãos e farelos) e Pecém/CE (combustíveis, grãos, frutas e carga geral).

Entre 2003 e 2013, mesmo sem haver grandes rupturas, houve uma importante recuperação da economia nacional, com base na expansão do crédito, nos investimentos em infraestruturas (Programa de Aceleração do Crescimento - PAC), nas parcerias comerciais Sul-Sul e outros. Estas ações, com base no planejamento e nos gastos/inversões públicos, criaram condições para elevação dos fluxos marítimos de mercadorias, dos empregos, da renda e do consumo internamente (fomento da demanda efetiva) (Figura 7).

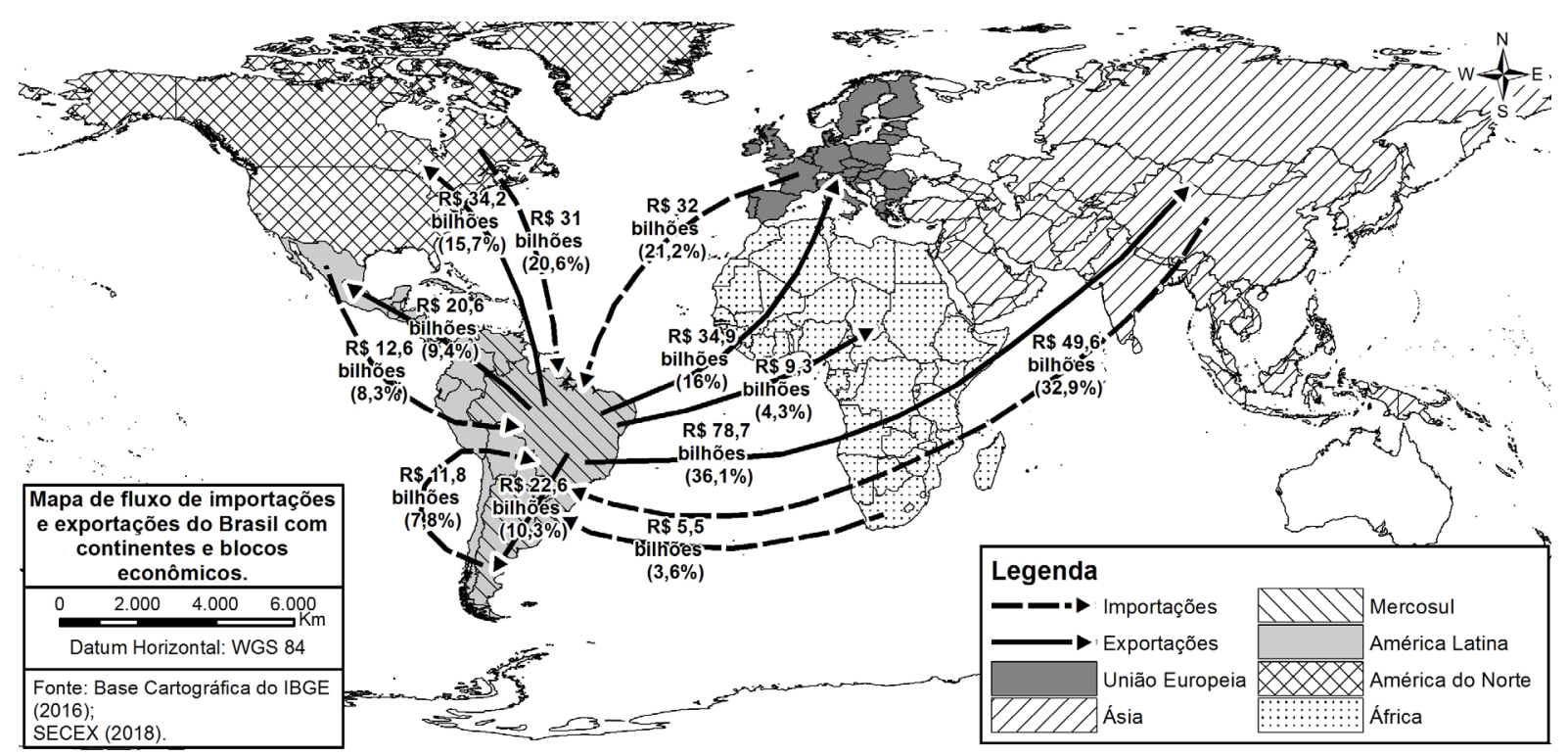

Figura 7. Fluxos de comércio do Brasil com continentes e blocos econômicos (bilhões de dólares), em 2017. Fonte: Secretaria de Comércio Exterior (SECEX), 2018 
Houve, nos governo de Luiz Inácio Lula da Silva e Dilma Rousseff, a expansão das relações Sul-Sul (periferia-periferia), com destaque às parcerias comerciais estabelecidas com países da África (Egito, Angola, Moçambique etc.), do Oriente-Médio (Irã), da Ásia (China e Índia, principalmente), do Leste Europeu (Polônia, Bulgária etc.), da América Latina (Peru, Venezuela, Cuba, Uruguai, Argentina, Colômbia, Paraguai e outros), além de valorizar o Mercosul para o desenvolvimento do Brasil e das demais nações. Essa estratégia possuiu dois aspectos relevantes, quais sejam: a) indicou uma postura anti-imperialista (de antagonismo à hegemonia dos Estados Unidos, sobretudo no contexto latino-americano); b) permitiu amenizar os impactos negativos da crise econômica internacional no país (principalmente nos anos de 2010, 2011 e 2012).

\section{As reestruturações do setor portuário e marítimo: alguns apontamentos}

As reestruturações produtivas e logísticas provocaram/provocam mudanças importantes na organização espacial das atividades econômicas e na divisão internacional do trabalho (DIT). A internacionalização econômica tem se acelerado com os avanços tecnológicos aplicados à informática, aos transportes e às telecomunicações. Para o capital produtivo e de transportes, isso significa dizer que se ampliaram as possibilidades e estratégias para a produção e a circulação, visando aproveitar as vantagens locacionais em diversos países, assim, reduz-se o custo e o tempo de transporte, e facilita-se a distribuição das mercadorias aos principais mercados consumidores. A mundialização do capital, a integração comercial e os avanços nas comunicações e nos meios e vias de transportes criaram a possibilidade de articular mais intensamente os diferentes mercados, mediante a formação de redes produtivas e logísticas apoiadas em inovações tecnológicas.

Há um processo de constituição de redes e fluxos conectando unidades de produção, sistemas logísticos e mercados consumidores. As firmas buscam integrar o espaço produtivo fragmentado através de uma logística pautada na eficiência organizacional, dessa maneira, o modal marítimo se consolida como grande responsável pelo transporte de mercadorias no mundo. Os fluxos de informações, bens e pessoas pressupõem a existência de redes físicas e organizacionais. A fluidez e a conectividade são fundamentais para a dinâmica econômica global. Isso representa a possibilidade de competir e conquistar mercados por meio da navegação e do comércio internacional, representando uma estratégia de inserção competitiva na economia mundial (Souza, 2008).

O sistema portuário e marítimo global, notadamente nas três últimas décadas, está passando por mudanças estruturais, na gestão, nas operações e na organização, já que esse espaço de fluxos se caracteriza pela capacidade organizacional e tecnológica de separar o processo produtivo em diferentes localidades, ao mesmo tempo em que garante conexões de telecomunicações e transportes para atender às demandas corporativas. As transformações tecnológicas, o fomento da intermodalidade e do uso de contêineres, a otimização das estratégias logísticas etc., buscam propiciar transportes e armazenamentos mais eficazes e seguros, de acordo com a lógica do just in time. O desenvolvimento do contêiner é resultado da necessidade de racionalizar o transporte, o manuseio da carga e a estadia das mercadorias nos portos e navios. Além disso, permitiu e estimulou a expansão da multimodalidade/intermodalidade, o aumento da capacidade e do tamanho das embarcações, o surgimento dos navios porta-contêineres, o transbordo eficaz dos produtos etc. Tais processos têm modificado a estrutura do transporte marítimo e dos portos no mundo (Souza, 2008). 
Destaca-se também a formação de uma rede global hierarquizada de portos, articulada pelos operadores do transporte marítimo, e cuja qualidade de conexão dos pontos nodais está cada vez mais relacionada à capacidade das empresas transportadoras em oferecer o serviço de forma segura, regular e ágil. A participação mais intensa de vários países periféricos no mercado internacional e o aprofundamento da divisão internacional do trabalho provocaram o aumento das trocas e a consolidação do eixo marítimo do Oceano Pacífico (destaque do bloco Ásia-Pacífico no comércio global). Ademais, surgiram novas estratégias de controle e competição no setor marítimo. Em 1970, dos vinte maiores portos em movimentação de contêineres, dezessete eram estadunidenses e/ou europeus, contudo, em 2014, dos vinte maiores portos, doze eram asiáticos, com destaque para seis portos chineses. Um outro reflexo desse processo é o avanço dos armadores asiáticos, pois dos vinte principais armadores do mundo, treze são da Ásia.

Os operadores logísticos foram/são relevantes na constituição de uma rede portuária hierarquizada global, que opera em diversas escalas assegurando às empresas ampla capacidade de distribuição de cargas. Para obter uma circulação mais fluida e reduzir os custos de transporte, as empresas realizam estratégias logísticas e competitivas no mercado: é o caso da formação de alianças. Atualmente, todas as grandes operadoras globais fazem parte desse tipo de associação e, por isso, essas empresas concentram a maior parte da capacidade de transporte, tornando-se grandes agentes na reorganização do sistema portuário-marítimo mundial. Nos anos de 1990, as empresas buscaram a expansão e uma melhor inserção na economia internacional. As alianças não são um processo recente, porém devido à crise internacional de 2008, elas se tornaram mais intensas e frequentes. Trata-se, acima de tudo, de uma estratégia que reduz custo, eleva a competitividade e garante o oligopólio setorial. Elas estão em constante transformação (principalmente mudando seus integrantes), seja para adaptarem a instabilidades do mercado ou ampliarem os serviços. Assim, tem-se a formação de redes de transportes globais que, através de tecnologias sofisticadas e técnicas de gestão de fluxos, articulam espaços produtivos, comerciais e de consumo dispersos no mundo (Souza, 2008).

Como consequência dessa dinâmica, muitas empresas pequenas e médias desapareceram e o mercado das linhas regulares tornou-se extremamente concentrado no setor marítimo. Ampliaram-se as necessidades de cobertura global dos serviços de transporte, diante disso, as estratégias de cartéis e de aumento da competitividade, os arranjos cooperativos para melhorar o desempenho, as inovações etc., resultaram em um número restrito de empresas de navegação que possuem destaque no setor marítimo internacional. Em 1995, dezesseis operadores possuíam $50 \%$ da capacidade de transporte, todavia, em 2010, sete empresas tinham essa capacidade. A busca por economias de escala reforça a tendência de concentração dos grandes grupos.

A finalidade de uma aliança consiste em adquirir maior controle sobre os fluxos e ampliar a cobertura geográfica dos serviços e, ao mesmo tempo, alcançar economias de escala de forma a tornar a circulação mais rápida e com custo menor. Tal condição leva à ampliação do tamanho/capacidade dos navios e, por consequência, a modernização dos portos. No entanto, se, por um lado, a escolha de um porto/terminal e o fomento de uma rota levam à concentração de cargas nos complexos portuários maiores e mais modernos, por outro, muitas vezes induzem à uma queda de demanda nos portos menores (Souza, 2008).

Diante disso, tem-se a formação de uma hierarquia portuária. No nível mais alto da rede estão os hubs globais localizados em pontos estratégicos nos corredores Leste-Oeste. Posteriormente, há os hubs regionais, nas rotas Norte-Sul, que, por sua vez, conectam-se com os portos menores sub-regionais e locais. Além da hierarquização portuária, há uma nítida diferenciação entre as rotas em termos de captação de fluxos, alocação da frota e concentração de operadores. As rotas Leste-Oeste são as preferenciais, portanto, 
onde estão os maiores fluxos, ligando as regiões do Hemisfério Norte (América do Norte, Europa e Ásia) de maior comércio; já as rotas Norte-Sul apresentam, em geral, menores valores agregados e quantidades movimentadas, sobretudo no que tange à carga geral e contêineres.

Novas linhas de transporte marítimo surgiram nos últimos anos no Brasil, expandindo o comércio, principalmente, entre o país e a Ásia (notadamente a China), caso, por exemplo, do crescimento das atividades do armador Maersk em Pecém/CE, Suape/PE e Rio Grande/RS; do Pacific International Lines (PIL) no Terminal de Navegantes/SC (Portonave) e no Porto de Paranaguá/PR; da Maersk, Mediterranean Shipping Company (MSC) e Cosco em Santos/SP; da CMA/CGM em Itaqui/MA; a utilização, pela empresa Vale do Rio Doce, de novos supernavios para transporte de minérios nos terminais de Ponta da Madeira/MA e Tubarão/ES; entre outros.

Na América Latina, essas mudanças foram/são observadas como resultado da dinâmica econômica regional, dos investimentos setoriais, das mudanças no sistema normativo e tributários e da presença dos grandes operadores portuários e marítimos. Com o objetivo de maximizarem a utilização de seus novos e grandes navios, as operadoras criaram linhas de distribuição em mercados regionais, como no Brasil, no México e no Panamá. Isso tornou-se mais notório, especialmente nos anos 2000, com a retomada do crescimento econômico e da demanda em vários países. Assim, foi necessário readequar as operações, os portos, as tecnologias, as estratégias logísticas e outros. Os principais produtos exportados pelos países latino-americanos são as commodities (menor valor agregado), como bauxita, carvão, grãos, farelos e minérios. Os principais destinos são os países europeus, os Estados Unidos e a China (Souza, 2008).

Nesse sentido, sobretudo nas duas últimas décadas, observam-se modernizações, concessões, arrendamentos e reformas portuárias em vários países latino-americanos. Além da fluidez, essas reformas buscaram/buscam também reduzir a burocracia e tornar as atividades mais rápidas e eficientes. As transformações portuárias e normativas são uma estratégia de inserção na economia global, mas ligadas muitas vezes aos interesses das empresas estrangeiras. Tais mudanças fomentam a competição interna, ou seja, entre os portos/terminais de uma região ou país, e até mesmo entre os países (caso, principalmente, de nações da América Central e Caribe), para captação de fluxos, sobretudo pelos hub ports regionais. Além disso, as alterações na legislação trabalhista também representam a adequação dos países aos interesses dos operadores logísticos, pois buscam a redução de custos com a mão de obra e o enfraquecimento dos sindicatos ligados ao setor portuário e marítimo. Essas mudanças são verificadas, por exemplo, no Brasil e no México.

Alguns armadores europeus e asiáticos estão realizando pesquisas e criando inovações para que o transporte marítimo utilize energias alternativas produzidas e patenteadas nos próprios países-sede. Tal estratégia está relacionada à busca por aumentar a competitividade dos grandes grupos e se adequar às leis ambientais mais rígidas, principalmente na União Europeia. Há vários experimentos testando o uso de etanol como combustível para navios na Europa. Em 2015, foi lançado o primeiro navio convertido para etanol: o Ferry de Passageiros Stena Germanica (Portal Marítimo, 2017).

Outra questão relevante diz respeito à conteinerização das cargas e ao fomento da intermodalidade/multimodalidade. Nos países desenvolvidos, tem-se um avanço nesse sentido, porém no Brasil há problemas graves que limitam a atividade portuária e a fluidez no território. Um exemplo é a falta de portos secos e terminais alfandegados na região Nordeste, o que limita as inversões do capital industrial e de transportes, prejudica o crescimento dos fluxos marítimos nos portos, sobretudo de carga geral em contêineres, entre outros, refletindo negativamente nos empregos, na renda e no 
efeito multiplicador regional. Esses fixos localizam-se, principalmente, no Centro-Sul do país, dinamizando a fluidez e a logística no espaço regional. É fundamental, assim como ocorre nos Estados Unidos, na União Europeia e na Ásia, haver fortes investimentos públicos e privados para expandir e qualificar as conexões intermodais no território. Não apenas nos corredores de exportação (como é predominante no Brasil), mas visando melhor articular e integrar o mercado e o território brasileiro. Tal fato é basilar para um projeto nacional de desenvolvimento.

Os armadores - diante da crise econômica global e da queda do preço dos fretes buscam eficiência em seus navios e operações e otimizam suas estratégias competitivas, não mais apenas pelo aumento do tamanho das embarcações, mas por meio de outros ganhos, como fusões, aquisições, acordos de compartilhamento de custos e investimentos, monopólios locais/regionais (caso, por exemplo, da empresa Vale do Rio Doce em terminais e linhas ferroviárias de nações africanas e do Brasil), terceirizações de atividades (manutenção de equipamentos e navios, por exemplo), joint ventures, compra e venda de ações no mercado financeiro internacional, influência nas políticas setoriais portuárias visando concentrar os financiamentos e recursos públicos em portos e terminais de interesse das grandes empresas, valorização do longo curso em detrimento da cabotagem (lucro maior), entre outros.

Considerando a complexidade do ambiente competitivo do mercado internacional, as empresas de navegação buscam estratégias focando não apenas na gestão logística e nas inovações, mas também buscam readequações no sistema normativo e tributário. Nesse sentido, destaca-se a União Europeia que realizou mudanças na legislação setorial, aumentando, por exemplo, a relação cidade-porto (a gestão portuária faz parte da política de desenvolvimento urbano, o que não ocorre efetivamente no Brasil), estabeleceu regras e tarifas comuns de alfandegamento, desburocratização rápida das cargas etc. O Brasil, por sua vez, ainda carece de um planejamento estratégico eficiente e adequações legais e fiscais para fomentar o setor.

A coordenação das decisões pelo grande capital, as inversões das corporações em novas tecnologias e a otimização da logística são elementos centrais da estratégia implementada pela Maersk, Cosco Shipping e outros armadores. A aliança entre as empresas exportadoras e importadoras e os prestadores de serviços logísticos, constituiu-se em importante mecanismo de construção de novas capacidades e competências, mitigando algumas perdas (financeiras, avarias nas cargas etc.). Considerando a relevante participação de empresas asiáticas no setor marítimo, destacam-se duas estratégias relevantes, quais sejam: a compra de ações de armadores ocidentais por empresas chinesas de navegação (com apoio do Estado), e a atuação forte dessas corporações no mercado financeiro e nas principais Bolsas de Valores do mundo.

A presença no mercado internacional exige, muitas vezes, a cooperação multilateral, caso dos joints realizados pelos armadores, sobretudo na última década. A experiência das empresas em realizar parcerias para mitigar custos revela que o sucesso da formação de uma aliança está baseado na identificação e seleção de parceiros, a partir de uma análise de competências e recursos, voltada a atender aos interesses e estratégias do capital privado. Como exemplos, têm-se os operadores de terminais de contêineres que realizam terceirizações para empresas de credibilidade (armadores que possuem grandes navios porta-contêineres, transportadoras rodoviárias com frota nova, rastreamento de cargas etc.).

Dessa maneira, identificar quais são as oportunidades que a aliança está criando e qual posição está garantindo aos parceiros, dentro do ambiente competitivo, é imprescindível, como as estratégias entre o Estado e a iniciativa privada chinesa, tanto na construção naval como em operadores de terminais e armadores (participações acionárias, 
subsídios, financiamentos a juros baixos, acordos de eficiência, investimentos, padronização fiscal e normativa etc.). A recente fusão entre a Cosco e a China Shipping elucida a estratégia de criar um grupo ainda mais forte no setor marítimo internacional.

Grandes armadores devem concentrar 90\% do mercado global de cargas marítimas em 2026, segundo estimativas de especialistas do setor. Os dez principais armadores mundiais, que na década de 1990 representavam quase 50\% do mercado internacional de transporte marítimo, alcançaram 83\% de participação em 2016 (MSC, Maersk/ Hamburg Süd, Cosco, China Shipping, Evergreen, CMA/CGM e outros). Os grandes armadores estão incorporando às suas frotas navios de 20 mil TEUs, o que aumenta a competitividade e eleva a demanda nos portos de maior capacidade operacional (profundidade, equipamentos modernos, agilidade nos processos de embarque e desembarque etc.) (Portal Marítimo, 2017).

Esse processo é reflexo de fusões, aquisições e formações de consórcios por parte dos grandes grupos mundiais de navegação. $\mathrm{O}$ excesso de oferta e a demanda insuficiente - decorrentes da crise econômica internacional - resultaram em uma queda do preço do frete de até $80 \%$ em algumas rotas, caso de linhas que atendem a África e a América Latina. Novos sistemas e tecnologias também estão estreitando as relações entre os principais armadores, levando diversas empresas menores de navegação, sobretudo de países periféricos, a perderem ainda mais mercado. Tal fato reforça o oligopólio setorial com ênfase aos armadores europeus e asiáticos.

Ademais, as fusões e incorporações ocorridas no setor estão reorganizando rotas com tendências a privilegiar ainda mais as linhas de comércio do Hemisfério Norte (América do Norte-Europa-Ásia). Diante disso, o número de diferentes serviços de longo curso nos portos brasileiros, que era de trinta e nove, em 2010, reduziu para vinte e um, em 2017, representando uma queda de 46\%. A movimentação nesse período variou de 115 mil TEUs para 105 mil TEUs, uma redução de 8,5\%. Diversos navios que atracaram nos portos brasileiros aumentaram a capacidade de 7 mil TEUs para 9,6 mil TEUs. Vários portos e terminais privados do mundo estão buscando estratégias e ações para atenderem à demanda dos grandes navios petroleiros, graneleiros, mistos e conteineros, especialmente nas principais rotas.

A profundidade de vários portos/terminais do mundo está acima de dezoito metros (Xangai, Roterdã, Cingapura, Ponta da Madeira etc.), porém muitos ainda não conseguiram atender a essas transformações e têm desafios na bacia de evolução, na dragagem, na modernização e outros. No Brasil, a logística portuária e um eficaz planejamento setorial de longo prazo precisam buscar soluções para se adequarem a essas mudanças. Isso depende de uma relação estratégica entre o poder público e a iniciativa privada, visando fomentar o desenvolvimento econômico nacional e modernizar ainda mais o setor portuário.

A crise econômica de 2008, combinada com a entrada de novos e grandes navios, resultou em uma baixa dos fretes. Consequentemente, os armadores passaram a adotar diversas medidas, dentre as quais a substituição dos navios mais antigos e menores por grandes embarcações, mais eficientes e capazes de gerar um custo unitário por TEU mais baixo. Entretanto, esse custo menor somente será obtido se o navio navegar com um nível de ocupação razoável. Assim, as empresas adotaram três medidas principais, quais sejam: reduzir custos, focar nas principais rotas comerciais e mercados consumidores, além das fusões, aquisições e formações de megaconsórcios.

Dessa maneira, nos últimos anos as principais fusões e aquisições no setor marítimo foram: a compra da Neptune Orient Lines pela CMA/CGM; a CSAV incorporada pela Hapag Lloyd; a CCNI comprada pela Hamburg Süd; a fusão da China Shipping e 
Cosco; a fusão da Hapag Lloyd com a UASC; a aquisição da Hamburg Süd pela Maersk; a fusão das três empresas japonesas (MOL, NYK e K Line); a falência da Hanjin; a formação de três grandes consórcios: 2M (Maersk e MSC); Ocean Aliance (CMA/ CGM, COSCO, OOCL, Evergreen); e The Aliance (Hapag Lloyd, NYK, MOL, K Line e Yang Ming) (Portal Marítimo, 2017).

Em âmbito mundial, verifica-se uma enorme concentração no mercado. A entrada de meganavios de 20 mil TEUs nos tráfegos Leste-Oeste gera um efeito cascata, em que os armadores tendem a deslocar outros navios para os tráfegos Norte-Sul, especialmente as linhas que servem a África e a América Latina (inclusive vários de grande capacidade, como 9,6 mil e 12 mil TEUs). Essas ações dos armadores forçam adequações do planejamento, do sistema normativo e tributário, da logística, das infraestruturas, das tecnologias e dos portos/terminais. O Brasil, por sua vez, não conseguiu avançar significativamente nesse sentido, apresentando ainda grandes gargalos setoriais (tangíveis e intangíveis). É necessário que muitos portos brasileiros possam se adaptar a essa nova dinâmica, caso, por exemplo, de vários estados da região Nordeste (Sergipe, Alagoas, Paraíba e Rio Grande do Norte, principalmente).

\section{As modernizações setoriais no Brasil}

O Estado brasileiro e as administrações locais e estaduais buscam, cada vez mais, prover seus territórios de sistemas de engenharia satisfatórios para fomentar a fluidez no espaço, visando tornarem-se mais competitivos, e definindo tais espaços como receptores do grande capital. Ao gestar o território com o desígnio de atender, sobretudo, aos interesses corporativos, o poder púbico elabora a logística de Estado (estratégia, planejamento e gestão estatal com a finalidade de imputar ao território maior fluidez e competitividade). Tal fato intensifica o poder de atração dos territórios em relação às empresas, caso, por exemplo, de segmentos varejistas e atacadistas, serviços diversos, centros de distribuição (CDs), terminais alfandegados, indústrias etc.

O Brasil, diante do contexto global, passou por importantes mudanças nos sistemas de transportes, armazenamento e logística, especialmente a partir dos anos de 1990, quais sejam: a) concessões de serviços públicos à iniciativa privada; b) introdução de novas estratégias logísticas, inovações organizacionais e tecnologias; c) desnacionalização da economia brasileira e predomínio das grandes corporações estrangeiras (fusões, aquisições e falências de firmas nacionais); d) reajustamento das empresas nacionais a um modelo de transportes, armazenamento e logística mais competitivo (custos, segurança, velocidade, tonelagens etc.); e) papel do Estado no provimento de infraestruturas diante das readequações das normas, tributações e do planejamento territorial voltados à fluidez corporativa.

As firmas passaram a ser mais flexíveis em relação aos tradicionais fatores de localização, sendo expresso pelo meio técnico-científico-informacional (Santos, 2002). É, portanto, nessa lógica que se observam transformações importantes nos sistemas de movimento e seus impactos nos territórios, como: a) reestruturações nas relações cidade-porto, bem como modernizações (organizacionais, técnicas, nos fixos, nos navios, nas normas etc.) no setor portuário e marítimo nacional e, sobretudo, internacional; b) maior amplitude dos fluxos aéreos, principalmente nas cidades de porte médio, formando novos hubs aeroportuários, reorientando, assim, a lógica que privilegiava a centralidade exacerbada de determinados espaços da rede urbana brasileira; c) formação de eixos de circulação nas rodovias com grande tráfego de veículos, surgindo, em muitos casos, "eixos de desenvolvimento", com intensos fluxos, com atração de atividades econômicas e população, além de um sistema de infovias margeando as rodovias (Sposito, 2015). 
A partir da década de 1980 nos países centrais e, mais intensamente a partir dos anos de 1990 no Brasil, as características principais da produção industrial foram modificadas na direção da integração horizontal das cadeias produtivas, dessa maneira, houve a fragmentação de diversas atividades tangíveis e intangíveis no espaço. Estas exigiram uma organização logística, dos transportes e das comunicações mais coerente para melhor articular subespaços longínquos, elevando-se a fluidez e reduzindo o tempo e o custo de circulação. Como exemplos, têm-se a expansão e modernização de navios e aviões (tamanho, velocidade, tecnologias, segurança etc.), a conteinerização (mercadorias refrigeradas, carga seca, granel sólido e granel líquido) e o armazenamento de qualidade (com maior agilidade na desburocratização das cargas).

A logística, por sua vez, otimiza a circulação no espaço, além de colaborar com os ganhos econômicos das corporações através da diminuição do tempo e dos custos de transportes. Isso, consequentemente, permite aumentar a competitividade. A logística modifica o espaço geográfico via ações corporativas, estatais e individuais. O conceito de logística privada/corporativa, segundo Silveira (2009), refere-se às estratégias que visam a otimização das atividades de armazenamento e transporte de mercadorias e pessoas. Não é, necessariamente, a base material (infraestruturas) ou os meios e vias de deslocamento no território, mas sim gestão, organização e estratégias voltadas à redução de custos e aprimoramento da mobilidade e fluidez no espaço.

A logística reduziu alguns obstáculos (gargalos físicos, operacionais e institucionais), ademais, houve uma maior racionalização de algumas normas, leis e procedimentos burocráticos (simplificação de processos aduaneiros e de movimentação, por exemplo), o que induziu a investimentos em fixos de transportes, de estocagem, em terminais intermodais e aduaneiros, em tecnologias da informação, e em técnicas de unitização e acondicionamento (caso do setor portuário e marítimo).

Como resultado da reestruturação produtiva e econômica, assim como da mundialização do capital, diversos centros de produção e distribuição surgiram, especialmente nas três últimas décadas, em países latino-americanos, asiáticos e, sobretudo na China, sendo uma lógica que o capital utilizou/utiliza para fomentar a acumulação privada e reduzir custos, principalmente em momentos de crise econômica internacional. Além do grande fluxo de capitais, força de trabalho e bens de consumo nesses países, destacase também o aumento das interações espaciais com o restante do mundo, atendendo demandas corporativas, econômica e humanas.

No que tange ao sistema normativo no Brasil, a antiga Lei 8.630/93 (denominada de Lei dos Portos) mudou o marco regulatório do setor. Seus principais objetivos eram: a) promover a descentralização do sistema portuário e marítimo brasileiro, inclusive através da estadualização e da municipalização dos portos (este fato foi consolidado a partir da criação da Lei 9.277/96); b) permitir que as operações portuárias e a movimentação de cargas fossem realizadas pelo capital privado (tinha-se, claramente, a intenção de reduzir os encargos e gastos estatais); c) fomentar a modernização portuária e do transporte marítimo de cargas, principalmente através da aquisição de novos equipamentos e novas tecnologias pelo setor privado; d) promover a concorrência no segmento para, em tese, levar à redução das tarifas de movimentação (tal fato acabou não ocorrendo, visto que intensificou-se o oligopólio estrangeiro e, portanto, as tarifas de movimentação variam muito pouco); e) promover a redução dos custos com trabalhadores portuários (houve aumento dos trabalhadores temporários e da subcontratação).

A Medida Provisória 595/2012, conhecida como MP dos Portos, e sancionada pela presidenta Dilma Rousseff como Lei 12.815/2013 (Nova lei dos Portos) pretende impulsionar a modernização dos complexos portuários do Brasil ao longo dos anos. Foram estabelecidos novos critérios para a exploração e arrendamento à iniciativa privada de 
terminais de movimentação de cargas. Além disso, as novas regras facilitam a instalação de novos terminais privados. O objetivo é ampliar os investimentos e modernizar o setor, a fim de baixar os custos de logística e melhorar as condições de competitividade da economia brasileira.

Segundo a antiga Lei dos Portos, de 1993, ganhava a licitação a empresa que pagasse o maior valor pela concessão do serviço portuário. Com a Nova Lei dos Portos, de 2013, passa a valer o critério de maior eficiência com menor tarifa, ou seja, maior movimentação possível de carga pelo menor preço por tonelada, o que é interessante para o desenvolvimento do setor no país. Essa estratégia é fundamental para carrear mais investimentos aos portos e terminais, fomentando, por conseguinte, a dinâmica econômica local, regional e nacional.

Os terminais de uso privado (TUPs), localizados fora do porto organizado, deixam de possuir a obrigatoriedade de movimentar somente cargas próprias. Cabe ao proprietário do terminal escolher se quer trabalhar apenas com mercadorias de terceiros ou com produtos de terceiros mais cargas próprias. Essa modalidade, baseada nas inversões da iniciativa privada, precisa de autorização do poder público, porém dispensa a licitação. Ademais, a nova lei definiu que os acordos coletivos envolvendo os trabalhadores portuários precisam ser realizados pelos sindicatos.

O sistema marítimo brasileiro é caracterizado pela desregulamentação, bem como pela existência de oligopólio estrangeiro, sendo intensificado pela legislação neoliberal criada na década de 1990 (Lei 8.630/93), mitigando a reserva de mercado para os armadores nacionais e abrindo o setor para o grande capital estrangeiro. Os principais armadores já dominavam o mercado internacional, porém isso torna-se mais forte no Brasil nesse período com a incorporação da Aliança pela Hamburg Süd, a falência da Netumar e a extinção do Lloyd Brasileiro. A concentração de capital no setor faz parte de um contexto técnico-econômico global, dos cartéis, das estratégias competitivas das grandes empresas, das inovações setoriais (grandes navios de cargas, tecnologias de informação e comunicação - TICs, rastreamento via satélite, monitoramento meteorológico etc.), mudanças do sistema normativo e tributário, reestruturações logísticas e outros, ou seja, não foi a Lei dos Portos que introduziu os navios de maior porte no Brasil, no entanto, o processo de oligopolização estrangeira no setor marítimo brasileiro se intensificou na década de 1990. Os principais armadores que atuam nos mais importantes portos do país são: Maersk (Dinamarca), Mediterranean Shipping Company (MSC) (Itália/Suíça) CMA/CGM (França), Mitsui/OSK Lines (Japão), Evergreen (Taiwan), Cosco Shipping (China) etc.

As concessões ligadas ao transporte marítimo de cargas refletem, muitas vezes, a frágil atuação do poder público, das Companhias Docas, da Agência Nacional de Transportes Aquaviários (ANTAQ) e outros na imposição de metas às concessionárias de transporte marítimo e de terminais, investimentos a serem realizados, fiscalização, liberdade de concorrência (às vezes os grandes armadores e os operadores de terminais pressionam o poder público no sentido de evitar a atuação de novas empresas no setor), cartelização do preço do frete, oligopólio estrangeiro, entre outros.

Ocorreram grandes transformações no transporte de cargas nas duas últimas décadas, tanto em relação às infraestruturas quanto à gestão logística e às operações. A maior integração econômica e comercial do Brasil a partir da década de 1990 gerou repercussões no setor marítimo nacional. A modernização portuária é importante para atender às demandas internas e externas (cabotagem, importações e exportações), com articulação entre os transportes, as comunicações e as informações. A incorporação de novas tecnologias (equipamentos, softwares, etc.) aumentou a eficiência e a produtividade portuária. 
As técnicas de unitização e de conteinerização para transferência e estocagem qualificaram os processos de movimentação e acondicionamento das cargas (notadamente no Brasil a partir dos anos de 1980). O transporte marítimo passou a utilizar-se intensamente dessas novas técnicas para otimização das operações, não apenas nos portos/terminais, mas também no interior dos navios. Isso garante maior segurança ao longo do trajeto realizado, pois evitam-se danos nas mercadorias (sobretudo nos bens industriais). Contudo, não apenas os produtos de maior valor agregado se utilizam do acondicionamento, visto que muitas vezes o transporte de café (e em menor medida de soja) também ocorre em contêineres.

Ademais, as cadeias logísticas mais complexas passaram a utilizar em maior escala o transporte aéreo para mercadorias com elevado valor agregado por unidade e/ou exigências de prazos, como produtos culturais, de alta tecnologia, do e-commerce e das indústrias farmacêuticas. Estas importam dos Estados Unidos, da Europa e da Ásia matérias-primas pelo aeroporto de Viracopos (Campinas/SP), por exemplo, todavia, uma parte dos procedimentos de alfandegamento de entrada no Brasil é realizado pelos portos secos, terminais alfandegados e Centros Logísticos Industriais Aduaneiros (CLIAs), como os existentes nos estados de Santa Catarina e São Paulo.

O transporte no território nacional é efetivado, em grande medida, por via rodoviária. Isso significa que há uma incipiente e deficiente articulação entre os diferentes modais. Quando ocorre a multimodalidade e/ou intermodalidade, esta é baseada mais nos subsídios de tributos do que na diminuição de custos logísticos e de transportes. O acréscimo da movimentação de passageiros, especialmente em alguns países periféricos, devido à expansão da classe média e do barateamento das passagens (low cost), também condicionou o desenvolvimento do transporte aéreo (sobretudo regional), surgindo, assim, novos hubs aeroportuários, caso de Campinas/SP.

As empresas trabalham cada vez mais com estoques reduzidos pelo sistema just in time, com um "giro" mais rápido nos armazéns e pátios e, dessa maneira, necessitam de maior agilidade nos transbordos. O aumento da eficiência operacional (tempo, custo e qualidade) é essencial na competição regional, nacional e global. Assim, ocorreram algumas mudanças no Brasil, como: a) a criação do Operador de Transporte Multimodal (OTM); b) o surgimento de terminais alfandegados, portos secos e CLIAs; c) o despacho aduaneiro simplificado; d) flexibilizações nos transportes aéreo e marítimo.

A participação do capital privado no setor portuário fomentou a modernização setorial. Nos principais portos e terminais privados do país (Santos/SP, Rio de Janeiro/RJ, Paranaguá/PR, Itajaí/SC, Navegantes/SC, Itapoá/SC, Rio Grande/RS, Suape/PE, Pecém/CE etc.), destacam-se: a) Ship Loaders automatizados (dutos com sistema de suç̧ão que realizam o carregamento e o descarregamento dos navios graneleiros); b) STS (Ship to Shore Crane) (portêineres), sendo grandes guindastes que retiram os contêineres dos pátios e os conduzem aos navios e vice-versa; c) RTG (Rubber Tyres Gantry) (transtêineres), são guindastes que movimentam os contêineres nos pátios dos terminais; d) MHC (Mobile Habour Crane), são guindastes para movimentar contêineres (tecnologia mais antiga); e) Reach Stackers (empilhadeiras e veículos especiais para movimentação de contêineres); f) Terminal Tractors (caminhões para movimentação de contêineres nos terminais); g) Softwares (Cosmos e Navys), realizam o controle de todas as operações realizadas nos terminais e fornecem as informações em tempo real; h) Scanners (utilizados para fiscalização e controle das mercadorias conteinerizadas); i) Contêineres especializados para cada tipo de mercadoria (carga seca, granéis líquidos, frigoríficos etc.); j) Navios Full Containers (embarcações especializadas no transporte de bens acondicionados); k) graneleiros (granéis sólidos) e mistos (líquidos e sólidos) de grande capacidade; 1) Sistema ISPS Code (International Ship and Port Facílity Security Code), que garante maior segurança no porto (câmeras e controle de pessoas, veículos e cargas); entre outros. 
Os navios porta-contêineres utilizados nas rotas marítimas entre o Brasil e o exterior estão cada vez maiores. Até o início da década de 2000, essas embarcações tinham capacidade para transportar 2,5 mil TEUs, contudo, nos últimos anos, a Maersk e outros armadores colocaram em operação nas linhas que servem o Brasil os primeiros de uma série de navios entre 7 mil e 9,6 mil TEUs (Antaq, 2017). Além do tamanho das embarcações, destaca-se a utilização do navio E-Ship 1 (cargueiro movido a energia eólica). Além da força dos ventos, usa motores a diesel e eletricidade (este já atracou nos portos de Santos/SP e Rio Grande/RS, por exemplo). Outra inovação é a embarcação parcialmente movida por uma "pipa gigante". A "pipa" é controlada por computador e sua eficiência depende das condições climáticas, mas a vantagem do sistema informacional Skysails (alemão) é que se aproveitam todas as direções do vento. A "pipa" não dispensa os motores, mas faz grande parte da função de movimentação do navio. É uma inovação que contribui para arrefecer o custo do transporte marítimo, bem como a emissão de poluentes (Portal Marítimo, 2017).

Ocorreram investimentos, sobretudo na última década, para aumentar a segurança portuária, caso, por exemplo, do Código Internacional para Segurança de Navios e Instalações Portuárias (International Ship and Port Facílity Security Code - ISPS Code). O ISPS Code estabelece determinadas regras que tornam os portos mais seguros, quais sejam: a) maior controle de entrada e saída de pessoas e veículos das instalações portuárias; b) delimitação do perímetro do porto; c) implantação de sistema de vigilância no porto organizado (câmeras e drones); d) cadastramento das pessoas e dos veículos que entram na área portuária; e) maior controle e fiscalização das mercadorias conteinerizadas (uso de scanner) (Secretaria Nacional de Portos, 2017).

A instalação do sistema Supervia Eletrônica de Dados (SED) e sua integração com o projeto Porto Sem Papel foi fundamental para confrontar as informações fornecidas pelos agentes marítimos (controle de cargas) e pelos operadores portuários (embarque e desembarque). Este sistema permite obter maior precisão no que tange a todas as movimentações efetuadas no Porto de Santos/SP, evitando-se, muitas vezes, o transporte de cargas com sonegação fiscal ou com peso alterado (Codesp, 2017).

Nos portos públicos brasileiros, está sendo elaborado um conjunto de ações denominadas de "Inteligência Logística Portuária". Entre as iniciativas está a implantação do Vessel Traffic Management Information System - VTMIS (Sistema de Gerenciamento e Informação do Tráfego de Embarcações). Trata-se de um avanço tecnológico importante para o setor no Brasil, pois o VTMIS já se encontra presente nos principais e mais movimentados portos/terminais no mundo.

O VTMIS é um sistema de auxílio eletrônico à navegação, com capacidade para monitorar o tráfego aquaviário. O objetivo do sistema é ampliar a segurança do transporte marítimo e a proteção ao meio ambiente nas áreas em que haja intensa movimentação de embarcações ou risco de acidente de grandes proporções (Secretaria Nacional de Portos, 2017).

A implantação do Banco de Dados Comum de Credenciamento (BDCC) aumentou a segurança no Porto de Santos/SP. As pessoas e os veículos que acessam o porto organizado, por meio de crachás eletrônicos, tem a sua identificação armazenada em um sistema informacional. Com esses dados, é possível obter maiores informações sobre os indivíduos e, caso retornarem ao porto, já terão seus dados armazenados nos computadores (Codesp, 2017).

Ademais, o Porto sem Papel é um sistema que visa reunir as informações e a documentação necessárias para agilizar a análise e a liberação das mercadorias nos portos brasileiros. Este já foi implantado na maioria dos portos públicos do país, eliminando muitos formulários em papel que foram convertidos para um único documento eletrônico. As informações são 
agregadas em um Documento Único Virtual (DUV) e transmitidas eletronicamente ao sistema, agilizando e desburocratizando vários processos (Secretaria Nacional de Portos, 2017).

Os principais portos/terminais privados do Sul do Brasil (Paranaguá/PR, São Francisco do Sul/SC, Itapoá/SC, Navegantes/SC, Itajaí/SC, Imbituba/SC e Rio Grande/RS), do Sudeste (Santos/SP, Rio de Janeiro/RJ, Itaguaí/RJ e Vitória/ES), do Nordeste (Pecém/CE, Itaqui/MA, Suape/PE e Salvador/BA) e do Norte (Manaus/AM e Belém/PA) receberam investimentos públicos e privados, especialmente na última década, aumentando, assim, a eficiência e competitividade (ainda que haja desigualdades entre eles em relação à modernização). Isso favoreceu/favorece a dinâmica econômica, reduz o tempo e o custo de circulação, eleva a segurança e a produtividade portuárias, atende às demandas corporativas de acumulação, bem como fomenta o desenvolvimento regional e nacional.

No que tange ao Programa de Aceleração do Crescimento (PAC) e, mais precisamente ao PAC-portos, buscou-se melhorar as operações portuárias e marítimas, compreendendo transbordo, aprofundamento da área de atracação, incorporação de novas tecnologias de comunicação e transporte, fomento da intermodalidade, qualificação dos equipamentos portuários (portêineres, transtêineres etc.), controle de cargas conteinerizadas e não conteinerizadas, fiscalização, entre outros. Não obstante, as inversões foram/são aquém do necessário e as obras públicas morosas. É importante haver o surgimento de novos terminais modernos no país, visando fomentar o setor portuário nacional, somado ao avanço da multimodalidade e ao surgimento de portos secos localizados estrategicamente nas regiões Norte e Nordeste do país.

Apesar da relativa modernização do setor portuário e marítimo brasileiro, há ainda diversos gargalos que prejudicam o desenvolvimento econômico nacional, quais sejam:

» Os congestionamentos nos portos e nas vias rodoviárias de articulação;

》 Ineficácia das ligações ferroviárias;

» Utilização demasiada do modal rodoviário para o transporte das cargas (importância do sistema intermodal, com maior utilização do modal ferroviário e hidroviário);

» Falta de modernização tecnológica em alguns portos (instalações e equipamentos obsoletos);

» Reduzida profundidade para navegação e/ou atracação de navios nos portos;

" Demora na liberação das cargas (sobretudo de importação);

" Necessidade de maior atuação estatal no sentido de impor metas de investimentos ao capital privado;

» Problemas nas rodovias (má sinalização e asfaltamento, falta de duplicação, obras paralisadas etc.);

»Diferentes valores do Imposto sobre Circulação de Mercadorias e Serviços (ICMS) cobrados pelos estados (muitas vezes os proprietários das cargas e os transportadores optam por rotas mais longas para reduzir os custos com o tributo e, assim, atrasam na chegada aos portos);

" Ineficiência das instituições que atuam no setor portuário e marítimo nacional (Agência Nacional de Transportes Aquaviários - ANTAQ, Secretaria Nacional de Portos, Companhias Docas, Autoridades Portuárias, Receita Federal etc.); 
Excessiva burocracia;

» Insuficiência dos recursos públicos e privados setoriais;

" Necessidade de estimular maiores inversões privadas (caso, por exemplo, do carreamento de recursos ociosos ao setor);

" Morosidade das obras infraestruturais;

" Corrupção;

» Falta de um planejamento setorial de médio e longo prazos (logística de Estado), com investimentos expressivos;

" Ajuste fiscal severo (desde 2014), impactando nas inversões em equipamentos e serviços públicos no Brasil etc.

Além desses, há outros desafios que precisam ser enfrentados no Brasil, como: as divergências frequentes entre as instituições envolvidas no setor portuário que dificultam projetos e ações; desequilíbrios regulatórios e tributários; guerra fiscal (caso, por exemplo, do Imposto sobre Serviços - ISS); burocratização dos procedimentos estatais (anúncio público, viabilidade locacional, excesso ou falta de garantias financeiras etc.); desinteresse da iniciativa privada, muitas vezes, em realizar investimentos em infraestruturas no território nacional (predomínio do capital financeiro e especulativo no país, em detrimento do produtivo); restrições/dificuldades aos investimentos públicos e privados (concentração da terra urbana e rural, problemas e insegurança jurídica existentes nos contratos, desapropriações onerosas etc.); falta de uma logística de Estado adequada voltada aos portos e que tenha continuidade ao longo do tempo; entre outros. É fundamental que essas questões sejam revistas, pois o setor precisa de expansão (capacidade antiociosa). Esse quadro dificulta/desestimula a realização de novos investimentos produtivos no país, impactando negativamente na geração de empregos e renda internamente. Precisa-se discutir o cenário atual do sistema portuário nacional no contexto de mudanças normativas/legais (notadamente, a aplicação de um novo modelo de concessão, adequadas parcerias público-privadas - PPPs, inversões maciças em fixos a partir do Programa de Investimento em Logística - PIL e do Programa de Aceleração do Crescimento - PAC etc.), visando retomar o desenvolvimento econômico do país.

\section{Considerações finais}

Um porto marítimo deve ser entendido como um complexo intermodal e componente (elo) da cadeia de distribuição internacional de mercadorias. O transporte marítimo (cabotagem e longo curso) é importante para a circulação do capital e para garantir a satisfação das demandas corporativas, econômicas e sociais.

Analisando o setor portuário e marítimo brasileiro ao longo do tempo (desde o período colonial), infere-se que a oferta sempre esteve aquém da demanda, isto é, os investimentos nos portos (instalações, equipamentos, infraestruturas etc.) sempre foram insuficientes para atender ao volume crescente do comércio exterior brasileiro e das trocas internamente. Assim, pontos de estrangulamento sempre existiram e prejudicaram a economia do país, afetando o setor produtivo (agropecuária e indústria) e, consequentemente, o nível de emprego e renda. 
Com o surgimento das novas demandas, sobretudo na segunda metade do século XX (industrialização, urbanização, diversificação da produção, elevação das importações e exportações, aumento da demanda interna etc.), foi-se consolidando um sistema portuário nacional mais interligado. Construção de rodovias integrando o território nacional e conectando o interior do país aos portos marítimos, expansão da rede de energia e telefonia, fomento do crédito/financiamentos, subsídios, dutovias e outros, permitiram o aumento da movimentação de cargas (grãos, farelos, manufaturas, bens de capital, petróleo e derivados, etanol, minérios etc.). Assim, infere-se que o desenvolvimento brasileiro ao longo das fases econômicas foi acompanhado por transformações regionais e na dinâmica do transporte marítimo, especialmente nos últimos sessenta anos.

Destacam-se cinco períodos que marcaram o setor portuário e marítimo brasileiro. O primeiro, que se estende durante o Império e o início da República (século XIX e começo do XX), foi dependente dos investimentos privados (sob concessão), sobretudo estrangeiros. O segundo, pós-1930, caracteriza-se por um Estado que assume a função de conduzir as inversões nos portos e no transporte marítimo, além de alavancar a indústria naval. O terceiro, pós-1990 (Lei 8.630/93), com fomento dos arrendamentos de terminais e da modernização portuária, é marcado pela queda dos investimentos públicos no setor e pela dependência das inversões privadas. O quarto teve início com as obras do PAC-portos (ainda que os recursos sejam insuficientes e as obras morosas), quando o Estado retoma os investimentos no setor após duas décadas de estagnação (dragagem, derrocagem, expansão de cais, berços e terminais, construção de molhes, avenidas perimetrais etc.). O quinto inicia-se em 2014 e estende-se até a atualidade, sendo resultado, principalmente, do ajuste fiscal severo implementado pelo governo federal (este, desde 2016, tornou-se ainda mais intenso com o governo de Michel Temer), assim, por um lado, reduziu-se bruscamente os investimentos públicos e, por outro, há uma (re)dependência das inversões privadas no setor portuário nacional.

O sistema marítimo brasileiro é concentrado nos portos do Sul e do Sudeste, sendo responsáveis por grande parte das importações e exportações nacionais (longo curso) - granéis sólidos, granéis líquidos e carga geral. O Porto de Santos/SP se destaca nos fluxos de bens industrializados e de contêineres (maior valor agregado), sendo um ponto nodal que atende à demanda, sobretudo, da Região Metropolitana de São Paulo, do interior do estado e do Centro-Oeste brasileiro. Não obstante, seu campo de influência extrapola os limites do território nacional, pois é responsável por parte das exportações e importações de outros países, caso do Paraguai e da Bolívia (hinterlândia supranacional).

O sistema marítimo brasileiro não é homogêneo. O estado de Santa Catarina possui diversos portos e terminais privados que "dividem" relativamente a demanda (desconcentração portuária), com destaque aos complexos especializados na movimentação de cargas conteinerizadas (Itajaí/SC, Navegantes/SC e Itapoá/SC). Similarmente, podem ser citados os estados da Bahia e do Rio de Janeiro (portos de Salvador/BA, Aratu/ BA, Rio de Janeiro/RJ e Itaguaí/RJ). Entretanto, nos estados de São Paulo, Paraná, Rio Grande do Sul, Pernambuco e Ceará verifica-se um processo diferente, já que existe uma grande concentração da movimentação de mercadorias em um único porto (Santos/ SP, Paranaguá/PR, Rio Grande/RS, Suape/PE e Pecém/CE).

A recuperação da economia brasileira, especialmente entre 2003 e 2013, gerou, consequentemente, o incremento dos fluxos marítimos e da circulação do capital, ao mesmo tempo em que criou necessidade de aprimoramento da logística privada para mitigação dos prejuízos decorrentes dos gargalos infraestruturais e satisfação da demanda interna e externa. Aumentaram as parcerias e as relações comerciais do Brasil com os BRICS, América do Sul e Central, África, Sudeste Asiático e Oriente Médio (periferia). A maior 
diversificação das trocas (Sul-Sul) foi/é importante para amenizar os impactos negativos da recessão econômica internacional e ainda permite o incremento das vendas externas de commodities e artigos industriais.

Há uma modernização incompleta no setor portuário brasileiro. Apesar dos avanços serem relativos (menos significativos em comparação aos principais países do mundo), houve um aumento no nível de competitividade e eficiência das operações portuárias, com incorporação de novas tecnologias (equipamentos, softwares etc.), mudanças normativas/legais e tributárias, aprimoramento da logística e outros. As transformações no sistema portuário e marítimo brasileiro, juntamente à maior integração comercial e econômica do país, fomentaram as importações e exportações. Modernos terminais, como o da Santos Brasil, Embraport e Brasil Terminal Portuário (BTP) (em Santos/ SP), APM Terminals, Portonave e Itapoá (em Santa Catarina), Wilson, Sons (em Rio Grande/RS) e Terminal de Contêineres de Paranaguá (TCP) (em Paranaguá/PR) são imprescindíveis para a dinâmica macroeconômica nacional.

O fomento do setor portuário e marítimo brasileiro depende de vários fatores, quais sejam: presença do Estado como agente planejador e indutor; existência de um qualificado planejamento setorial de médio e longo prazos (logística de Estado), resultando em investimentos expressivos; aumentar as inversões públicas e privadas; impulsionar a modernização tecnológica e organizacional; realizar adequadas concessões de serviços públicos à iniciativa privada; estimular o carreamento de recursos ociosos ao setor (antiocioso); expandir os financiamentos públicos e privados; assegurar reserva de mercado para a cabotagem e o longo curso e reduzir os afretamentos de navios estrangeiros; expansão das encomendas da Petrobras e da Transpetro na indústria naval brasileira (offshore, cabotagem e longo curso); estimular o surgimento de estaleiros e armadores nacionais (estatais e privados); planejamento e ações para fomentar a cabotagem; reduzir a burocracia em relação aos investimentos públicos e privados no país; acabar com a morosidade na liberação dos recursos públicos; acelerar a realização das obras infraestruturais; expansão da multimodalidade/intermodalidade etc.

Há necessidade de acelerar e fomentar as obras do PAC-portos, bem como as licitações para novos arrendamentos em portos do país, pois isso é importante para aumentar as inversões públicas e privadas no setor portuário brasileiro. A falta de uma logística de Estado eficiente impede um arrefecimento mais expressivo das deficiências infraestruturais que prejudicam o desenvolvimento econômico brasileiro. Nesse sentido, destaca-se a relevância de uma maior articulação entre os governos federal, estaduais e municipais no planejamento portuário e marítimo estratégico, já que no Brasil as divergências político-partidárias impedem a criação de um projeto nacional.

Além da expansão dos complexos portuários já existentes, propõe-se a construção de portos regionais, principalmente voltados à cabotagem, em pontos estratégicos do território brasileiro. Estes, sendo dotados de instalações e conexões intermodais qualificadas, são importantes para fomentar o desenvolvimento regional e nacional. Destaca-se ainda, a estratégia de criação de empresas estatais e privadas de cabotagem e longo curso (armadores) - que utilizam navios e embarcações construídos no país - para impulsionar a indústria naval internamente.

O crescimento da movimentação de mercadorias nos portos brasileiros, como na região Nordeste (portos de Pecém/CE, Suape/PE, Salvador/BA e Itaqui/MA, por exemplo), apesar da recessão econômica interna, elucida as inovações ocorridas no setor, sobretudo na última década, envolvendo mudanças normativas/legais, tributárias, fiscais, logísticas, técnicas, nos fixos e nas estratégias competitivas, favorecendo o incremento da circulação do capital, dos fluxos e das redes envolvendo o transporte marítimo de cargas (cabotagem e longo curso). 


\section{Q Bibliografia}

»Associação Brasileira dos Terminais de Contêineres de Uso Público (ABRATEC) (2017). Informações e dados estatísticos. Rio de Janeiro.

" BAHIA (2017). Companhia Docas do Estado da Bahia (CODEBA). Informações e dados estatísticos. Salvador.

» Baltar, C. T. (2007). Padrão do comércio brasileiro no período 2003-2005: um estudo do conteúdo dos fluxos de importação e exportação. Dissertação de Mestrado. UNICAMP. Campinas.

» Barat, J. (2007). Logística e transporte no processo de globalização: oportunidades para o Brasil. São Paulo: Edunesp.

»Belluzzo, L. G. (2017). Desencontros do desemprego. In: Carta Capital. Disponível em: https://www.cartacapital.com.br/revista/960/desencontrosdo-desemprego. Acesso em: 03 de agosto de 2017.

»Brasil. (2017, 2018). Agência Nacional de Transportes Aquaviários (ANTAQ). Dados estatísticos. Brasília.

"Brasil. (2017). Companhia Docas do Estado de São Paulo (CODESP). Informações e dados estatísticos. Santos.

"Brasil. (2018). Instituto de Pesquisa Econômica Aplicada (IPEA). Relatórios e dados estatísticos. Brasília.

» Brasil. (2017). Ministério do Desenvolvimento, Indústria e Comércio Exterior. Secretaria de Comércio Exterior (SECEX). Dados estatísticos. Brasília.

» Brasil. (2017). Ministério dos Transportes, Portos e Aviação Civil. Secretaria Nacional de Portos. Dados estatísticos. Brasília.

» Brito, P. (2010). Muito a navegar: uma análise logística dos portos brasileiros. São Paulo: TOP Books.

"Carvalho, C. E. (2009). A intervenção estatal na crise e a crise do neoliberalismo. In: Sister, S. (Org.). O abc da crise. São Paulo: Fundação Perseu Abramo, p. $165-176$.

»Ceará (2017). Companhia de Integração Portuária do Ceará (CEARÁPORTOS). Informações e dados estatísticos. Pecém, São Gonçalo do Amarante.

"Chesnais, F. (1996). A mundialização do capital. São Paulo: Xamã.

» Cocco, G.; Silva, G. (1999). Cidades e portos: os espaços da globalização. Rio de Janeiro: DP\&A.

»Cocco, R. G. (2011). Interações espaciais e sistemas de transporte público: uma abordagem para Bauru, Marília e Presidente Prudente. Dissertação de Mestrado em Geografia. Presidente Prudente: FCT/UNESP.

" Corrêa, R. L. (1997). Interações espaciais. In: CASTRO, I. E de; CORRÊA, R. L.; GOMES, P. C da C. (Org.) Explorações geográficas. Rio de Janeiro: Bertrand Brasil, p. 279-318.

" Coutinho, P. C. et al. (2013). Identificação dos principais mercados existentes no setor portuário. Relatório 3. Centro de Excelência em Regulação de Mercados. Brasília: Universidade de Brasília. 
» Faria, S. F. S. (1998). Transporte aquaviário e a modernização dos portos. São Paulo: Aduanas.

" Felipe Junior, N. F. (2014). Circulação, transportes e logística no setor portuário e marítimo brasileiro. Vila Velha: Above.

» Felipe Junior, N. F. (2012). Dinâmica econômica e recentes transformações no transporte marítimo de cabotagem e longo curso no Brasil: alguns apontamentos sobre a modernização portuária no Estado de São Paulo. Tese de Doutorado em Geografia. Presidente Prudente: FCT/UNESP.

»Figueiredo, G. S. (2000). O papel dos portos concentradores na cadeia logística global. In: XX ENEGEP. São Paulo.

" Fonseca, R. O. (2012). A circulação através da navegação de cabotagem no Brasil: um sistema de fluxos e fixos aquaviários voltados para a fluidez territorial. Dissertação de Mestrado em Geografia Humana. Faculdade de Filosofia, Letras e Ciências Humanas da Universidade de São Paulo, Departamento de Geografia. São Paulo.

»Fonseca, R. O. (2015). A navegação de cabotagem de carga no Brasil. In: Mercator, 14, (1), 21-46.

" Fromm, G. (1968). Transporte e desenvolvimento econômico. Rio de Janeiro: Victor Publicações.

" Gonçalves, A.; Nunes, L. A. de P. (2008). O grande porto: a modernização no Porto de Santos. Santos: Realejo Edições.

"Goularti filho, Alcides. (2007). Melhoramentos, reaparelhamentos e modernização dos portos brasileiros: a longa e constante espera. In: Economia e Sociedade, 16, 3 (31), 455-489.

"Hoffmann, J. (2008). Después de las concesiones portuarias. Exponaval.

»Itajaí (2017). Autoridade Portuária de Itajaí. Informações e dados estatísticos. Itajaí.

» Junqueira, L. A. P. (2003). Desafios da modernização portuária. São Paulo: Aduaneiras.

» Keynes, J. M. (1982). A teoria geral do emprego, do juro e da moeda. São Paulo: Atlas.

"Lacerda, S. M. (2004). Navegação e portos no transporte de contêineres. In: Revista do BNDES, 11, (22), 215-243.

» Lacerda, S. M. (2004). Transporte marítimo de longo curso no Brasil e no mundo. In: Revista do BNDES, 11, (21), 209-232.

»Laxe, F. G. (2005). Puertos y transporte marítimo: ejes de una nueva articulación global. In: Revista de Economía Mundial. Huelva.

" Laxe, F. G.; Seoane, J. F. (2003). Economía del transporte marítimo. Coruña: Netbiblo.

" Lima, E. T.; Velasco, L. O. M. de. (2000). As novas empresas mundiais de navegação determinam a evolução dos portos. In: Revista do BNDES. Brasília.

» Ludovico, N. (2010). Logística de transportes internacionais. São Paulo: Saraiva.

» Mccalla, R. J.; Slack, B.; Comtois, C. (2004). Dealing with globalization at the regional and local level: the case of contemporary containerization. The Canadian Geographer, 48, (4). 
» Marx, K. (2005). O capital: crítica da economia política (livros 1 e 2). Rio de Janeiro: Civilização Brasileira.

" Medina, A. C. et al. (2010). Análise da competitividade da indústria marítima brasileira e um panorama do setor de cabotagem no Brasil e no exterior: uma visão da indústria da construção naval brasileira e seus principais atores. São Paulo: Iglu.

» Miglioli, J. (2004). Acumulação de capital e demanda efetiva. São Paulo: Hucitec.

» Neu, M. F. R. (2009). Os portos do sul do Brasil: da formação ao século XXI. Tese de Doutorado em Geografia. São Paulo: Universidade de São Paulo (USP).

»Notteboom, T.; Rodrigue, J. P. (2007). Containerization, box logistics and global supply chains: the integration of ports and liner shipping networks. In: Maritime Economics \& Logistics, special 1oth anniversary issue.

"Oliveira, C. T. de (2011). Modernização dos portos. São Paulo: Aduaneiras.

"Padua, C. de A.; Serra, E. G. (2006). Superação dos gargalos logísticos do setor portuário. Revista do BNDES, 13, (26), 55-88.

"Pernambuco (2017). Complexo Industrial Portuário de Suape. Informações e dados estatísticos. Cabo de Santo Agostinho, Ipojuca.

»Pons, J. M. S.; Reynés, M. R. M. (2004). Geografía de los transportes. Palma: Universitat de les Illes Balears, Servei de Publicacions i Intercanvi Científic.

»Portal Marítimo (2017). Informações e dados estatísticos sobre transporte marítimo e o setor portuário brasileiro. Disponível em: http://portalmaritimo. com/. Acesso em: 05 de dezembro de 2017.

» Rangel, I. (2005). Obras reunidas (vol. 1 e 2). Rio de Janeiro: Contraponto.

» Reis, H. dos S. (2011). O espaço portuário de São Sebastião no contexto da Geografia Portuária Brasileira. Dissertação de Mestrado em Geografia. São Paulo: Faculdade de Filosofia, Letras e Ciências Humanas da Universidade de São Paulo.

» Rodrigue, J. P., Comtois, C.; Slack, B. (2009). The Geography of Transport Systems. New York: Routledge.

»Sánchez, R. J. et al. (2007). El transporte marítimo internacional de América Latina y el Caribe hacia finales del año 2006. Boletín Fal Edición, 253, CEPAL/ ONU.

»Sánchez, R. J. (2003). Las reformar portuária en America latina. CEPAL/ONU. Mérida, México.

"Sánchez, R. J. (2008). Tendencias del transporte marítimo internacional hacia una estrategia logística. México: CEPAL/ONU.

» Sánchez ALBAVERA, Fernando (2005). Latin American Ports and Transport Infrastructure Challenges. Houston: CEPAL/ONU.

"Santos, M. (2002). A natureza do espaço: técnica e tempo, razão e emoção. São Paulo: Edusp.

"Silveira, M. R. (2009). As cinco revoluções e evoluções logísticas e seus impactos sobre o Brasil. In: Lamoso, L. P.; Mourão, P. F. C.; Silveira, M. R. (Org.). Questões nacionais e regionais do território brasileiro. São Paulo: Expressão Popular.

" Silveira, M. R. (Org.) (2011). Circulação, transportes e logística: diferentes perspectivas. São Paulo: Outras Expressões. 
» Silveira, M. R. (2007). Estradas de ferro no Brasil: das primeiras construções às parcerias público-privadas. Rio de Janeiro: Interciência.

"Souza, E. M. R. (2008). Alianças, América Latina e sistema marítimo portuário mundial. In: Encontro de Geógrafos da América Latina (EGAL). Montevidéu.

»Sposito, E. S. (Org.) (2015). O novo mapa da indústria no início do século XXI: diferentes paradigmas para a leitura das dinâmicas territoriais no estado de São Paulo. São Paulo: Edunesp.

»Stopford, M. (2009). Maritime Economics. London and New York: Routledge.

"Tavares, M. da C. (2009). Entupiu o sistema circulatório do capitalismo. In: SISTER, S. (Org.). O abc da crise. São Paulo: Fundação Perseu Abramo, p. 67-70.

» Terminal de Itapoá (2017). Informações e dados estatísticos. Itapoá.

"Trevisan, L. (2015). Os operadores logísticos e o uso do território brasileiro: racionalidade e fluidez. In: Mercator, Fortaleza, 14, (1), 21-46.

\section{Nelson Fernandes Felipe Junior / nelfelipejr@hotmail.com}

Possui graduação em Geografia pela Universidade Estadual Paulista (UNESP), campus de Presidente Prudente. É mestre e doutor em Geografia pela mesma instituição. Atualmente, é professor adjunto do Departamento de Geografia e do Programa de Pós-graduação em Geografia da Universidade Federal de Sergipe (UFS), campus de São Cristóvão. Pesquisador do Grupo de Estudos em Desenvolvimento Regional e Infraestruturas (GEDRI), do Laboratório de Circulação, Transportes e Logística (LABCIT) e coordenador do Núcleo de Estudos sobre Transportes (NETRANS). 